\title{
Circulating and disseminated tumor cells: diagnostic tools and therapeutic targets in motion
}

\author{
Hongxia Wang ${ }^{1, *}$, Nikolas H. Stoecklein ${ }^{2, *}$, Peter P. Lin ${ }^{3}$ and Olivier Gires ${ }^{4,5}$ \\ ${ }^{1}$ Department of Oncology, Shanghai General Hospital, Shanghai Jiao Tong University School of Medicine, Shanghai, P.R. \\ China \\ 2 Department of General, Visceral and Pediatric Surgery, Medical Faculty, University Hospital of the Heinrich-Heine-University \\ Düsseldorf, Düsseldorf, Germany \\ ${ }^{3}$ Cytelligen, San Diego, California, USA \\ ${ }^{4}$ Department of Otorhinolaryngology, Head and Neck Surgery, Grosshadern Medical Center, Ludwig-Maximilians-University \\ of Munich, Munich, Germany \\ ${ }^{5}$ Clinical Cooperation Group Personalized Radiotherapy of Head and Neck Tumors, Helmholtz, Germany \\ * These authors have contributted equally to this work \\ Correspondence to: Hongxia Wang, email: whx365@126.com \\ Olivier Gires, email: olivier.gires@med.uni-muenchen.de
}

Keywords: CTCs, DTCs, metastases, EpCAM, MICs

Received: April 25, $2016 \quad$ Accepted: September 20, $2016 \quad$ Published: September 24, 2016

\section{ABSTRACT}

Enumeration of circulating tumor cells (CTCs) in peripheral blood with the gold standard CellSearch ${ }^{\mathrm{TM}}$ has proven prognostic value for tumor recurrence and progression of metastatic disease. Therefore, the further molecular characterization of isolated CTCs might have clinical relevance as liquid biopsy for therapeutic decision-making and to monitor disease progression. The direct analysis of systemic cancer appears particularly important in view of the known disparity in expression of therapeutic targets as well as epithelial-to-mesenchymal transition (EMT)-based heterogeneity between primary and systemic tumor cells, which all substantially complicate monitoring and therapeutic targeting at present. Since CTCs are the potential precursor cells of metastasis, their in-depth molecular profiling should also provide a useful resource for target discovery. The present review will discuss the use of systemically spread cancer cells as liquid biopsy and focus on potential target antigens.

\section{INTRODUCTION}

Metastasis is the major cause of cancer-related death [1]. Growing evidence supports the notion that locally invading, blood-borne circulating tumor cells (CTCs) and disseminated tumor cells (DTCs) in bone marrow and lymph nodes are precursors of recurrent tumors and metastases. So far, the development of targeted therapies was mostly fueled by knowledge related to primary tumor biology and, currently, around one dozen therapeutic antibodies and 28 different inhibitors are in clinical application, targeting essentially the tumor antigens HER2, EGFR, EpCAM, BRAF and VEGF [25]. These therapeutic agents have been primarily approved for late stage advanced disease with recurrent tumors and/or distant metastases [2-4]. Owing to technical and study limitations, the above mentioned therapeutics are barely in use to target (occult) precursors of recurrence and metastases in first-line therapies. In fact, currently available therapeutic agents are generally applied when cellular precursors have already deployed their capacities and disease has progressed. Nevertheless, efforts to enumerate occult systemic cancer cells and to transfer molecular therapies to earlier, less progressed stages of disease have been undertaken in breast cancer [6-9], which hopefully represents a trailblazer for other entities.

In order to change treatment regimens towards more effective suppression of metastasis, two aspects are paramount. Firstly, a more accurate staging including diagnosis of the systemic disease is mandatory, in order to define patients at increased risk to relapse and/or to develop metastases. Such diagnostics must detect clinically occult systemic cancer that is currently not assessable by routine diagnostics. In our opinion, CTCs 
and DTCs appear to be good candidates to achieve this aim. Secondly, reliable and validated assays for detection and molecular analysis of CTCs/DTCs are required in the therapeutic context, which is currently very challenging in the adjuvant situation. The technologies required for such molecular characterization of CTCs and DTCs should optimally enable not only assessment of known therapeutic targets, e.g. HER2, EGFR, and EpCAM, but also comprehensive profiling to identify novel therapeutic targets. Such molecular staging becomes even more important in the adjuvant situation in light of reported discordances in expression patterns of several therapeutic targets in primary tumors versus CTCs and DTCs [10-14]. It appears therefore mandatory, to determine the exact target expression in systemic cancer cells to select the correct adjuvant therapy in the non-metastatic, high-risk situation in the context of precision medicine.

In the present review, we will discuss advantages and challenges related to CTCs and DTCs as diagnostic tools and therapeutic targets in motion. We will briefly summarize knowledge on enumeration and characterization, and extend on potential molecular targets on the cells of systemic cancer.

\section{CTCS AS LIQUID BIOPSIES}

Reliable biomarkers for molecular staging of disease progression and risk evaluation of carcinomas have, as yet, entered clinical routine only for a subset of tumor entities, such as the PSA protein in prostate cancer. In this context, CTCs could play a role as "liquid biopsy" through their direct molecular characterization to obtain comprehensive "on-line" information on the extent and the molecular phenotypes of systemic cancer $[12,15-20]$. In the metastatic situation, CTCs have prognostic significance in various tumor entities (Table 1). In a large cohort of non-metastatic primary breast cancer patients $(n=3173)$, one or more CTCs were found in approximately $20 \%$ of individuals at the time of first diagnosis and strongly correlated with larger tumors, nodal involvement, and poor disease outcome [21]. Hence, CTCs are also detectable in the adjuvant, non-metastatic situation, although at reduced rates and numbers, and have prognostic impact.

Compared to CTCs, DTCs are further advanced cancer cells since they have already settled in distant organs such as the bone marrow or lymph nodes [22]. As such, DTCs might harbor valuable information concerning the metastatic potential of the disease and deserve therefore intensive analyses of associated antigens, which might represent therapeutic targets. For example, expression of EpCAM on DTCs of esophageal cancer patients was restricted compared to primary tumors, but correlated with lymph node involvement and remarkably poor outcome [10]. It must be noted however, that in comparison to CTCs, the detection of DTCs is more invasive, given the need for bone marrow puncture or surgery in case of lymphatic DTCs. For these reasons, longitudinal monitoring of DTCs is barely possible for routine clinical applications.

In the metastatic situation, CTC-based liquid biopsies might not only identify the right patients for more effective therapies but could help avoid futile treatment in de novo resistant cancers. Few initial experiments suggested that short-term in vitro expansion and testing of metastatic breast cancer CTCs permits prediction of the patient's response to drugs [23, 24]. But it is important to cautiously note that such short term CTC cultures are far from being validated clinical applications. Given the extremely few publications in this field and the numerous groups world-wide working on CTCs, it is obviously very difficult to establish reliable CTC culture systems. However, besides their enumeration, distinct molecular characteristics of CTCs were reported to predict recurrence and treatment response [25]. For example, more mesenchymal CTCs were associated with disease progression and treatment resistance in metastatic breast cancer [25], which is in line with the recently discovered function of EMT in chemoresistance in mouse models of metastatic breast and pancreatic cancer [26, 27]. Comparably, CTCs in prostate cancer can display androgen receptor (AR) expression and signaling transitions that could provide valuable information for second-line therapy with adequate inhibitors [28].

In the adjuvant, non-metastasized situation, enumeration of CTCs also has prognostic significance and indicates patients with risk for systemic progression $[21,29-31]$, with the potential to improve therapy and patient care. For instance, the increase of selected, more aggressive CTC phenotypes in patients clinically staged $\mathrm{N}_{0} / \mathrm{M}_{0}$ could represent a rationale for enhanced adjuvant treatment to prevent recurrence and metastases. As example, the presence of CTCs in locally advanced head and neck cancer patients after chemotherapy was predictive of poor survival except for oropharyngeal cancers, suggesting that CTCs have the potential to define patients who would profit from intensified therapy [32, 33]. Here, molecular staging could help to decide upon the timing to change or reinforce radiation and tailor systemic therapy regimens.

Pre-clinical and clinical trials including CTCs and DTCs for various clinical purposes are underway and address CTC enumeration as well as molecular characterization of a plethora of antigens (Table 1 and 2). For example, the potential of CTC numbers as a criterion for treatment decisions was addressed in the prospective randomized SWOG S0500 trial [34]. CTC counts were used to stratify metastatic breast cancer patients for continued standard therapy or for a treatment arm composed of an alternative chemotherapy. Unfortunately, the CTC-informed alternative chemotherapy had no beneficial effect on OS and PFS [34]. This negative result might be explained by selectivity issues of the 
Table 1: Current molecular markers for the identification and therapeutic targeting of CTCs and DTCs in solid cancers

\begin{tabular}{|c|c|c|c|}
\hline Biomarker & Expression rate & Drug & Description \\
\hline \multicolumn{4}{|l|}{ Markers for CTCs } \\
\hline ЕрСАМ & $37-42.3 \%$ & Panorex, MT201, MT101, ING-1 & \begin{tabular}{|l} 
- \\
FDA-approved CellSearch ${ }^{\mathrm{TM}}$ system depends on EpCAM- \\
specific capturing of CTCs in various cancers [21,30, 47, \\
49, 125, 127,258-262] \\
Loss of EpCAM on CTCs as a result of dynamic phenotypic \\
changes during EMT[11,35, 150,151,263]
\end{tabular} \\
\hline CD44 & $35.2 \%$ & Pan-CD44 antibody H90 & $\begin{array}{ll}\text { - } & \text { CD44 expression in CTCs of HNSCC, breast, gastric and } \\
\text { endometrial cancer patients }[46,264-268]\end{array}$ \\
\hline ALDH1 & $17.7-80 \%$ & ATRA, DEAB & $\begin{array}{ll}\text { - } & \text { ALDH1 expression in CTCs of breast, non-small cell lung } \\
\text { and endometrial cancer patients [36, 264, 266, 267, 269] }\end{array}$ \\
\hline CD133 & $83 \%$ & $\begin{array}{l}\text { CART } 133 \text { chimeric antigen receptor } \\
\text { (CAR) T cells }\end{array}$ & $\begin{array}{l}\text { - Expression of the cancer stem cell marker CD133 in } \\
\text { CTCs of metastatic breast, colon, colorectal, renal cell, } \\
\text { hepatocellular and non-small cell lung cancer patients [266, } \\
269-275]\end{array}$ \\
\hline FGF2 & n.a. & Dovitinib, Pentraxin-3 & $\begin{array}{ll}\text { - } & \begin{array}{l}\text { Frequent secretion of FGF2 by CTCs in pM1-staged } \\
\text { prostate cancer [276] }\end{array} \\
\end{array}$ \\
\hline KRT7, KRT18, KRT19 & $46.9 \%$ & Anti-KRT19 antibody HPA002465 & $\begin{array}{ll}\text { - } & \text { KRT7, } 18 \text { and } 19 \text { expression in CTCs from ovarian, gastric } \\
\text { and gastroesophageal cancer patients [277, 278] } \\
\text { - } \begin{array}{l}\text { Used for therapy monitoring of advanced NSCLC and } \\
\text { breast cancer[279] }\end{array}\end{array}$ \\
\hline c-Met+/CD47+ & $0.8-33.3 \%$ & Hu5F9-GA, ARG 197 & $\begin{array}{l}\text { CD44/c-Met/CD47 CTCs from breast cancer patients } \\
\text { display metastatic potential [46] } \\
\text { c-Met+/CD47+ CTCs as novel independent prognosticator } \\
\text { of OS in luminal breast cancer [154,236] } \\
\text { c-Met as a capture antigen for CTCs and as a therapeutic } \\
\text { target [237, 238, 280] } \\
\text { CD47 expression on CTCs of colorectal cancer [239, 281] }\end{array}$ \\
\hline HER2 & $7.9-35.9 \%$ & $\begin{array}{l}\text { Herceptin, Pertuzumab, Lapatinib, } \\
\text { Trastuzumab-mertansine (T-DM1) }\end{array}$ & $\begin{array}{l}\text { - HER2 expression on CTC of metastatic breast, non-small } \\
\text { cell lung, gastric, gastrointestinal, ovarian cancer [12, 13, } \\
36,119,178,189,282] \\
\text { Anti-HER2 therapy to address HER2-positive CTCs [283] } \\
\text { HER2 is part of the signature of breast cancer CTCs } \\
\text { competent for brain metastases [284] }\end{array}$ \\
\hline EGFR & $18-56 \%$ & $\begin{array}{l}\text { Cetuximab, Afatinib, Erlotinib, } \\
\text { Gefitinib, Panitumumab }\end{array}$ & $\begin{array}{l}\text { - EGFR expression on CTCs of colorectal, prostate, non- } \\
\text { small cell lung, gastric, head and neck, and breast cancer } \\
\text { [32,36,121,210,283, 285-288] } \\
\text { Treatment resistance T790M EGFR mutation in CTCs of } \\
\text { non-small cell lung cancer [289] } \\
\text { Lapatinib treatment of metastatic breast cancer patients with } \\
\text { EGFR-positive CTCs [290] } \\
\text { EGFR is part of the signature of breast cancer CTCs } \\
\text { competent for brain metastases [284] }\end{array}$ \\
\hline MUC1/16 & $28.1-90 \%$ & ASI402 & $\begin{array}{ll}\text { - } & \begin{array}{l}\text { Expression of mucin } 1 \text { and } 16 \text { in CTCs from ovarian cancer } \\
\text { patients [277] }\end{array} \\
\end{array}$ \\
\hline HPSE & n.a. & PI-88 & $\begin{array}{l}\text { - } \quad \text { Breast cancer CTCs express heparanase [291] } \\
\text { HER2/EGFR/HPSE/Notch1-positive breast cancer CTCs } \\
\text { have brain metastastic potential [284] }\end{array}$ \\
\hline Androgen receptor & $16.3-18 \%$ & Bicalutamide, Flutamide & $\begin{array}{l}\text { - Nuclear expression of androgen receptor splice variant } 7 \\
\text { protein in CTCs of metastatic castration-resistant prostate } \\
\text { cancer is a treatment-specific biomarker that is associated } \\
\text { with superior survival on taxane therapy over ARS-directed } \\
\text { therapy }[288,292]\end{array}$ \\
\hline Telomerase & n.a. & Imetelstat & $\begin{array}{l}\text { - Telomerase activity on CTC of metastatic prostate cancer is } \\
\text { a prognostic marker [293] } \\
\text { Telomease-sensitive adenovirus as diagnostic and } \\
\text { therapeutic tool against CTCs in various cancer [294, 295] }\end{array}$ \\
\hline Vimentin & $32.3 \%$ & Withaferin-A, Silibirin, Quercetin & $\begin{array}{l}\text { - } \begin{array}{l}\text { Decrease OS of castration-resistant prostate cancer patients } \\
\text { with vimentin/ki-67-positive CTCs [296] }\end{array} \\
\end{array}$ \\
\hline Ki-67 & $20.8-45.1 \%$ & n.a. & $\begin{array}{l}\text { - } \quad \text { Ki67 expression in CTCs of metastatic breast cancer [297, } \\
298]\end{array}$ \\
\hline M-30 & $10-76.63 \%$ & M30 CytoDeath ${ }^{\mathrm{TM}}$ ELISA & 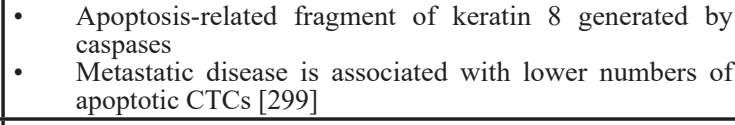 \\
\hline TWIST1 & n.a. & $\begin{array}{l}\text { Curcumin, SFN, Quercetin, } \\
\text { CADPE, Moscatilin, NAC, BMP7, } \\
\text { Claudins }\end{array}$ & $\begin{array}{l}\text { - TWIST1 is expressed in CTCs of breast cancer patients } \\
\text { along with further EMT and stem cell markers [269] }\end{array}$ \\
\hline uPAR & n.a. & $\begin{array}{l}\text { PAI-1, anti-uPAR antibody 10G7, } \\
\text { WX-UK1, Mesupron }\end{array}$ & 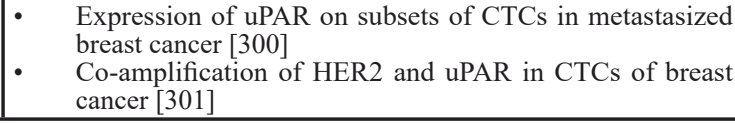 \\
\hline
\end{tabular}




\begin{tabular}{|c|c|c|c|}
\hline \multicolumn{4}{|l|}{ Markers for DTCs } \\
\hline CD44 & $33-100 \%$ & Pan-CD44 antibody H90 & CD44 expression on most breast cancer DTCs [302] \\
\hline Survivin & n.a. & ISIS23722, EM-1421 & $\begin{array}{l}\text { - Survivin expression in bone marrow-resident DTCs in } \\
\text { colorectal cancer [303] }\end{array}$ \\
\hline TWIST1 & $31 \%$ & $\begin{array}{l}\text { Curcumin, SFN, Quercetin, } \\
\text { CADPE, Moscatilin, NAC, BMP7, } \\
\text { Claudins }\end{array}$ & $\begin{array}{l}\text { - TWIST1 expression in bone marrow-resident DTCs in non- } \\
\text { metastatic breast cancer }[304,305]\end{array}$ \\
\hline uPAR & $58 \%$ & $\begin{array}{l}\text { PAI-1, anti-uPAR antibody 10G7, } \\
\text { WX-UK1, Mesupron }\end{array}$ & $\begin{array}{l}\text { uPAR expression on DTCs of localized prostate cancer is an } \\
\text { adverse prognostic marker [306] }\end{array}$ \\
\hline $\begin{array}{l}\text { Thomsen-Friedenreich } \\
\text { antigen }\end{array}$ & $98 \%$ & JAA-F11 & $\begin{array}{ll}\text { - } & \text { Thomsen-Friedenreich antigen is expressed on bone } \\
\text { marrow-resident breast cancer DTCs [307] }\end{array}$ \\
\hline HER2 & $43 \%$ & $\begin{array}{l}\text { Herceptin, Pertuzumab, Lapatinib, } \\
\text { Trastuzumab-mertansine (T-DM1) }\end{array}$ & $\begin{array}{l}\text { - HER2 expression on DTCs in breast, ovarian and } \\
\text { esophageal cancer [67,282, 308] } \\
\text { - Gain of HER2 expression in esophageal cancer DTCs } \\
\text { confers high risk of early death [67] } \\
\text { - HER2 expression on breast cancer DTCs as a prognostic } \\
\text { marker for OS and PFS [309-311] } \\
\text { 52\% concordance of HER2 expression on primary tumor } \\
\text { and DTCs in patients with early breast cancer [312] }\end{array}$ \\
\hline EGFR & $15-88 \%$ & $\begin{array}{l}\text { Cetuximab, Afatinib, Erlotinib, } \\
\text { Gefitinib, Panitumumab }\end{array}$ & $\begin{array}{ll}\text { - } & \text { EGFR expression on breast, colorectal and gastrointestinal } \\
\text { cancer DTCs [313-315] } \\
\text { - } \\
\text { Cancer-specific EGFRvIII mutant as a marker of breast } \\
\text { cancer DTC [316] } \\
\text { - } & \text { EGFR and FGF2 promote amplification of DTCs }\end{array}$ \\
\hline FGF2 & n.a. & Dovitinib, Pentraxin-3 & \\
\hline NUAK1 & n.a. & WZ4003 & \multirow{4}{*}{$\begin{array}{l}\text { Differential expression of NUAK1, PIN4, MALT1, and } \\
\text { CDC25B in single prostate cancer DTC defines dormant } \\
\text { subtypes .[317] }\end{array}$} \\
\hline PIN4 & n.a. & Anti-PIN4 antibody EPR10033 & \\
\hline MALT1 & n.a. & EP603Y & \\
\hline CDC25B & n.a. & Anti-CDC25B antibody S353 & \\
\hline CEA & $0-84 \%$ & n.a. & $\begin{array}{l}\text { - CEA expression on breast, colorectal, and gastric cancer } \\
\text { DTCs }[315,318,319]\end{array}$ \\
\hline EрCAM & $28.5-$ & Panorex, MT201, MT101, ING-1 & $\begin{array}{ll}\text { - } & \text { Expression of EpCAM on non-small cell lung, breast, } \\
\text { rectal, ovarian, prostate cancer DTCs [176, 317, 320-324] } \\
\text { - } & \text { EpCAM-positive DTCs as therapeutic targets [323] } \\
\text { Frequent loss of EpCAM expression on bone marrow- } \\
\text { resident DTCs in esophageal cancer patients [10] }\end{array}$ \\
\hline
\end{tabular}

MUC: mucin; ALDH1: aldehyde dehydrogenase isoform 1;CD47: cluster of differentiation 47; EGFR: epidermal growth factor receptor; FDA: food and drug administration; EMT: epithelial-mesenchymal transition; mCRPC: metastatic castration resistant prostate cancer; HPSE; N-acetylcysteine, NAC; Caffeic acid 3,4-dihydroxy-phenethyl ester; uPAR: urokinase-type plasminogen activator receptor; MRD: minimal residual disease; CEA:carcinoembryonic antigen.

n.a.: not applicable.

CellSearch ${ }^{\mathrm{TM}}$ system [35], heterogeneity of CTCs $[11,35,36]$, general resistance to chemotherapy, and eventually - and most likely - the choice of the alternative chemotherapy. Beyond that one first trial, enumeration of CTCs (also with CellSearch ${ }^{\mathrm{TM}}$ system) could be still predictive in a different clinical setting and several trials are currently ongoing to further investigate these aspects [15] (Table 2). First pilot phase results of the international EORTC 90091-10093 Treat CTC, phase 2 proof-ofconcept trial (NCT01548677) have been disclosed very recently [37]. Here, CTCs are monitored in form of liquid biopsy in HER2-negative breast cancer patients (adjuvant and neo-adjuvant situation). Patients with detectable CTCs after radio-chemotherapy are stratified to an observational arm and a treatment arm, implementing the anti-HER2 antibody Trastuzumab [37]. So far, $11 \%$ of patients ( $n$ = 350) had detectable, treatment-resistant CTC after standard adjuvant treatment, out of which 26 patients (7.4\%) have been randomized to either study arm. Results related to the efficacy of Trastuzumab to eradicate CTCs and clinical endpoints such as recurrence-free survival, invasive DFS, DFS and OS are expected two years after the last patients will have been randomized [37].

While the discussed increasing trial activity testing CTC-based liquid biopsy in metastasized patients is encouraging, a comprehensive transfer to the adjuvant situation is missing. The major bottleneck here is the rarity of CTCs in the M0 situation and the low blood volume ( < $10 \mathrm{~mL}$ ) usually investigated, insufficient to reliably detect the few CTCs present [15, 16, 19, 20, 38]. A potential solution to overcome this problem might be the use of diagnostic leukapheresis (DLA), which enables densitybased pre-enrichment from large blood volumes (liters) and thereby the screening of liters of blood for CTCs [39]. However, this approach must be validated in larger cohorts with respect to feasibility and prognostic value [15, 39].

Alternative to CTC/DTC based liquid biopsies, circulating tumor DNA (ctDNA) has been extensively investigated for diagnostic and prognostic purposes [40]. ctDNA is released into the circulation by tumor cells following apoptosis and necrosis, and represent a comparably simple tool for the analysis of systemic disease $[41,42]$. ctDNA isolation can be performed from serum and blood plasma, requires less sophisticated technologies 
Table 2: Selection of ongoing trials related to CTCs of solid tumors. (According:https://clinicaltrials.gov/; assessment date:08/11/2016)

\begin{tabular}{|c|c|c|c|c|c|}
\hline $\begin{array}{l}\text { ClinicalTrials.gov } \\
\text { Identifier }\end{array}$ & Title/study & \begin{tabular}{|l|} 
No of \\
patients
\end{tabular} & Time period & Primary endpoints & Cancer type \\
\hline \multicolumn{6}{|c|}{ CTCs as biomarkers or therapeutic targets } \\
\hline NCT01548677 & $\begin{array}{l}\text { Trastuzumab in HER2-negative Early } \\
\text { Breast Cancer as Adjuvant Treatment for } \\
\text { Circulating Tumor Cells (CTC) ("TREAT } \\
\text { CTC" Trial) }\end{array}$ & 2175 & Apr 2013- Dec 2018 & CTCs detection & Breast cancer \\
\hline NCT01619111 & $\begin{array}{l}\text { DETECT III - A Multicenter, } \\
\text { Randomized, Phase III Study to Compare } \\
\text { Standard Therapy Alone Versus Standard } \\
\text { Therapy Plus Lapatinib in Patients With } \\
\text { Initially HER2-negative Metastatic Breast } \\
\text { Cancer and HER2-positive Circulating } \\
\text { Tumor Cells }\end{array}$ & 120 & Feb 2012-Mar 2018 & CTC clearance rate & Breast cancer \\
\hline NCT01975142 & $\begin{array}{l}\text { Validity of HER2-amplified Circulating } \\
\text { Tumor Cells to Select Metastatic Breast } \\
\text { Cancer Considered HER2-negative } \\
\text { for Trastuzumab-emtansine (T-DM1) } \\
\text { Treatment. }\end{array}$ & 480 & Oct 2013-Nov 2016 & $\begin{array}{l}\text { Tumor response rate to } \\
\text { T-DM1 in patients with } \\
\text { HER2 amplified CTCs }\end{array}$ & Breast cancer \\
\hline NCT01349842 & $\begin{array}{l}\text { CirCe01 Study: Evaluation of the Use } \\
\text { of Circulating Tumour Cells to Guide } \\
\text { Chemotherapy From the 3rd Line of } \\
\text { Chemotherapy for Metastatic Breast } \\
\text { Cancer }\end{array}$ & 568 & Jan 2010-Jan 2018 & OS & Breast cancer \\
\hline NCT00382018 & $\begin{array}{l}\text { S0500 Treatment Decision Making } \\
\text { Based on Blood Levels of Tumor Cells } \\
\text { in Women With Metastatic Breast Cancer } \\
\text { Receiving Chemotherapy }\end{array}$ & 651 & Oct 2006-May 2017 & OS, PFS & Breast cancer \\
\hline \multicolumn{6}{|c|}{ Predictive, diagnostic and prognostic value of CTCs } \\
\hline NCT02610764 & $\begin{array}{l}\text { Pilot Study: Resectable Esophageal } \\
\text { Adenocarcinoma and the Relevance of } \\
\text { CTC (ESO-CTC) }\end{array}$ & 20 & Nov 2015-Dec.2017 & $\begin{array}{l}\text { Changes } \\
\text { numbers }\end{array}$ & Esophageal cancer \\
\hline NCT02035813 & $\begin{array}{l}\text { DETECT IV - A Prospective, Multicenter, } \\
\text { Open-label, Phase II Study in Patients } \\
\text { With HER2-negative Metastatic Breast } \\
\text { Cancer and Persisting HER2-negative } \\
\text { Circulating Tumor Cells (CTCs). } \\
\end{array}$ & 520 & Jan 2014-Dec 2019 & PFS & Breast cancer \\
\hline NCT01322893 & $\begin{array}{l}\text { Enumeration and Molecular } \\
\text { Characterization of Circulating Tumor } \\
\text { Cells in Women With Metastatic Breast } \\
\text { Cancer }\end{array}$ & 150 & Mar 2011-Dec 2016 & CTC numbers & Breast cancer \\
\hline NCT02626039 & $\begin{array}{l}\text { Characterization \& Comparison of } \\
\text { Drugable Mutations in Primary and } \\
\text { Metastatic Tumors, CTCs and cfDNA in } \\
\text { MBC patients (MIRROR) }\end{array}$ & 40 & Nov 2013-Dec 2016 & $\begin{array}{l}\text { Mutations and genomic } \\
\text { alterations in primary } \\
\text { tumor tissue and } \\
\text { metastases }\end{array}$ & Breast cancer \\
\hline NCT02119559 & $\begin{array}{l}\text { Assessment of Circulating Tumor Cells as } \\
\text { an Early Predictive Marker of Response } \\
\text { to a First Line Treatment Based on an } \\
\text { Anti-Human Epidermal Growth Factor } \\
\text { Receptor (HER), Cetuximab, in Patients } \\
\text { With Inoperable Recurrent and/or } \\
\text { Metastatic HNSCC. }\end{array}$ & 115 & Sep 2012-Mar 2018 & $\begin{array}{l}\text { Predictive value of CTCs } \\
\text { on PFS }\end{array}$ & $\begin{array}{l}\text { Head and neck } \\
\text { squamous } \\
\text { carcinoma }\end{array}$ \\
\hline NCT02554448 & $\begin{array}{l}\text { Detection of CTCs in Stage III Rectal } \\
\text { Cancer Patients Undergoing Neoadjuvant } \\
\text { Therapy }\end{array}$ & 80 & Jan 2016-Dec 2016 & CTC numbers & Rectal cancer \\
\hline
\end{tabular}




\begin{tabular}{|c|c|c|c|c|c|}
\hline NCT01596790 & $\begin{array}{l}\text { Assessment by EPISPOT of Circulating } \\
\text { Tumor Cells as an Early Predictive } \\
\text { Marker of Response to Chemotherapy } \\
\text { and Targeted Therapy in Patients With } \\
\text { Metastatic Colorectal Cancer in First Line } \\
\text { of Treatment }\end{array}$ & 168 & Apr 2012-Apr 2016 & $\begin{array}{l}\text { Predictive value of CTCs } \\
\text { on PFS }\end{array}$ & Colorectal Cancer \\
\hline NCT01848015 & $\begin{array}{l}\text { Prediction of Recurrence in Advanced } \\
\text { Gastric Cancer After Radical Resection } \\
\text { by Circulating Tumor Cells (CTCs) }\end{array}$ & 200 & Jun 2013-Jul 2016 & $\begin{array}{l}\text { CTC as predictive } \\
\text { marker for recurrence }\end{array}$ & Gastric cancer \\
\hline NCT01625702 & $\begin{array}{l}\text { Clinical Significance of Circulating } \\
\text { Tumor Cells (CTCs) in Blood of Patients } \\
\text { With Advanced/Metastatic Gastric Cancer }\end{array}$ & 100 & Jun 2012-Dec 2015 & $\begin{array}{l}\text { CTC as prognostic } \\
\text { marker }\end{array}$ & Gastric cancer \\
\hline NCT02072616 & $\begin{array}{l}\text { Detection of Circulating Tumor Cells } \\
\text { for the Diagnostic of Pancreatic } \\
\text { Adenocarcinoma }\end{array}$ & 142 & Sep 2014-Sep 2021 & $\begin{array}{l}\text { Sensitivity of CTCs as } \\
\text { diagnostic marker }\end{array}$ & Pancreatic cancer \\
\hline NCT02451384 & $\begin{array}{l}\text { Comparison of the Influences of Different } \\
\text { Methods to Remove the Pancreatic Ductal } \\
\text { Adenocarcinoma on the Detection of } \\
\text { Circulating Tumor Cells }\end{array}$ & 45 & Jul 2015-Dec 2016 & $\begin{array}{l}\text { CTCs between the pre } \\
\text { and post-operation in } \\
\text { each study arm }\end{array}$ & $\begin{array}{l}\text { Pancreatic ductal } \\
\text { adenocarcinoma }\end{array}$ \\
\hline NCT02155426 & $\begin{array}{l}\text { A Multicenter, Prospective, Observational } \\
\text { Trial on the Prognostic and Dynamic } \\
\text { Change of CTC Enumeration in } \\
\text { Advanced NSCLC With 1st or 2nd Line } \\
\text { Chemotherapy and Targeted Therapy }\end{array}$ & 1200 & Apr 2014-Dec 2016 & Baseline CTC count & $\begin{array}{l}\text { Non-small cell lung } \\
\text { cancer }\end{array}$ \\
\hline NCT02407327 & $\begin{array}{l}\text { Individualized Treatment of Patients With } \\
\text { Advanced NSCLC: Potential Application } \\
\text { for Circulating Tumor Cells (CTC) } \\
\text { Molecular and Phenotypical Profiling } \\
(2012 / 52)\end{array}$ & 150 & Dec 2013-Dec 2017 & $\begin{array}{l}\text { Percentage of CTC- } \\
\text { positive patients and } \\
\text { total CTC numbers }\end{array}$ & $\begin{array}{l}\text { Non-small cell lung } \\
\text { cancer }\end{array}$ \\
\hline NCT02500693 & $\begin{array}{l}\text { Circulating Tumor Cells and Early } \\
\text { Diagnosis of Lung Cancer in Patients } \\
\text { With Chronic Obstructive Pulmonary } \\
\text { Disease }\end{array}$ & 600 & Nov 2015-Dec 2019 & CTC detection rate & Lung cancer \\
\hline NCT02372448 & $\begin{array}{l}\text { Multicenter Validation of the Sensitivity } \\
\text { of Theranostic ALK Rearrangement } \\
\text { Detection by FISH Analysis and } \\
\text { Prevalence of Escaping Mutations in } \\
\text { Circulating Tumor Cells for the Non- } \\
\text { invasive Management of Lung Cancer } \\
\text { Patients }\end{array}$ & 224 & Jul 2014-Jul 2016 & $\begin{array}{l}\text { Sensitivity and } \\
\text { specificity of the FISH } \\
\text { technique in CTC } \\
\text { assessment }\end{array}$ & Lung cancer \\
\hline NCT02666612 & $\begin{array}{l}\text { Measurement and Characterization } \\
\text { of Circulating Endothelial Cells or } \\
\text { Circulating Tumor Cells in Adult Patients } \\
\text { With Metastatic Cancer }\end{array}$ & 1000 & Aug 2008-Aug 2020 & CEC and CEP rate & Metastatic cancer \\
\hline NCT01961713 & $\begin{array}{l}\text { Circulating Tumor Cell Analysis in } \\
\text { Patients With Localized Prostate Cancer } \\
\text { Undergoing Prostatectomy }\end{array}$ & 200 & Apr 2010-Apr 2019 & CTC numbers & Prostate cancer \\
\hline
\end{tabular}

PFS: Progression Free Survival; OS: Overall Survival CEC: circulating endothelial cells; EPC: endothelial progenitors cells

and is less cost intense. For instance, cancer personalized profiling by deep sequencing (CAPP-Seq) was applied for the case of non-small cell lung cancer and demonstrated the presence of ctDNA in $100 \%$ of stage II-IV patients and $50 \%$ of stage I patients [43]. ctDNA levels correlated with tumor burden and outperformed radiographic approaches with respect to treatment response assessment [43]. As such, ctDNA analysis might represent a complementary tool to the CTC analysis [44, 45]. Despite obvious advantages of simplicity for the isolation and analysis through standardized deep-sequencing methods, ctDNA clearly harbors several drawbacks compared to the enumeration and characterization of CTCs and DTCs. While ctDNA-based diagnostic is currently closer to clinical routine use, CTCs and DTCs allow the analyses at genomic, transcriptomic, and proteomic levels, whereas 
ctDNA analysis remains restricted to genomic alterations. Furthermore, CTCs and DTCs can be further studied in vitro for resistance traits $[23,24]$ and in vivo in animal models for their metastatic capacity [46]. Thereby, the gain of knowledge acquired through the analysis of CTCs and DTCs is incomparably more comprehensive. Thus, CTCs (and possibly DTCs) represent superior candidates for liquid biopsy since they have the potential to reflect disease progression and therapy response at multiple biological levels [25, 47-53]. However, substantial challenges remain in efficient enrichment, detection, and isolation of CTCs due to potential loss of capture antigens during EMT [11, $15,16,35,54-57]$, in usage as liquid biopsy owing to the small volumes of peripheral blood currently analyzed [15, $19,58]$, in genetic and molecular profiling to enhance our knowledge of the metastatic cascade [22, 59-69], and in therapeutic targeting at the earliest time points to attack the very cells possibly responsible for lethal metastases $[16,20,57,70-81]$.

\section{CTCS AND DTCS AS PRECURSORS OF METASTASES: HINTS AND EVIDENCE}

So far, the true metastatic potential of CTCS remains largely unclear. The metastatic cascade is initiated by detachment from primary tumors, local invasion and intravasation into the blood. When the invasive cancer cells become blood-borne they are called CTCs. After extravasation at secondary sites, the cancer cells can settle and are then termed DTCs (Figure 1) [54, 70, 71, 82-84]. The actual time point of the metastatic spread remains a highly interesting question. Does the metastatic cascade represent a late process requiring dissemination of fully malignant cells from locally advanced tumors or is it the result of early spread of distinct cells that undergo coevolutionary changes parallel to the primary tumor [22, $61,69,85]$ ? Malignant cells that are less changed by evolutionary developments within the primary tumor but
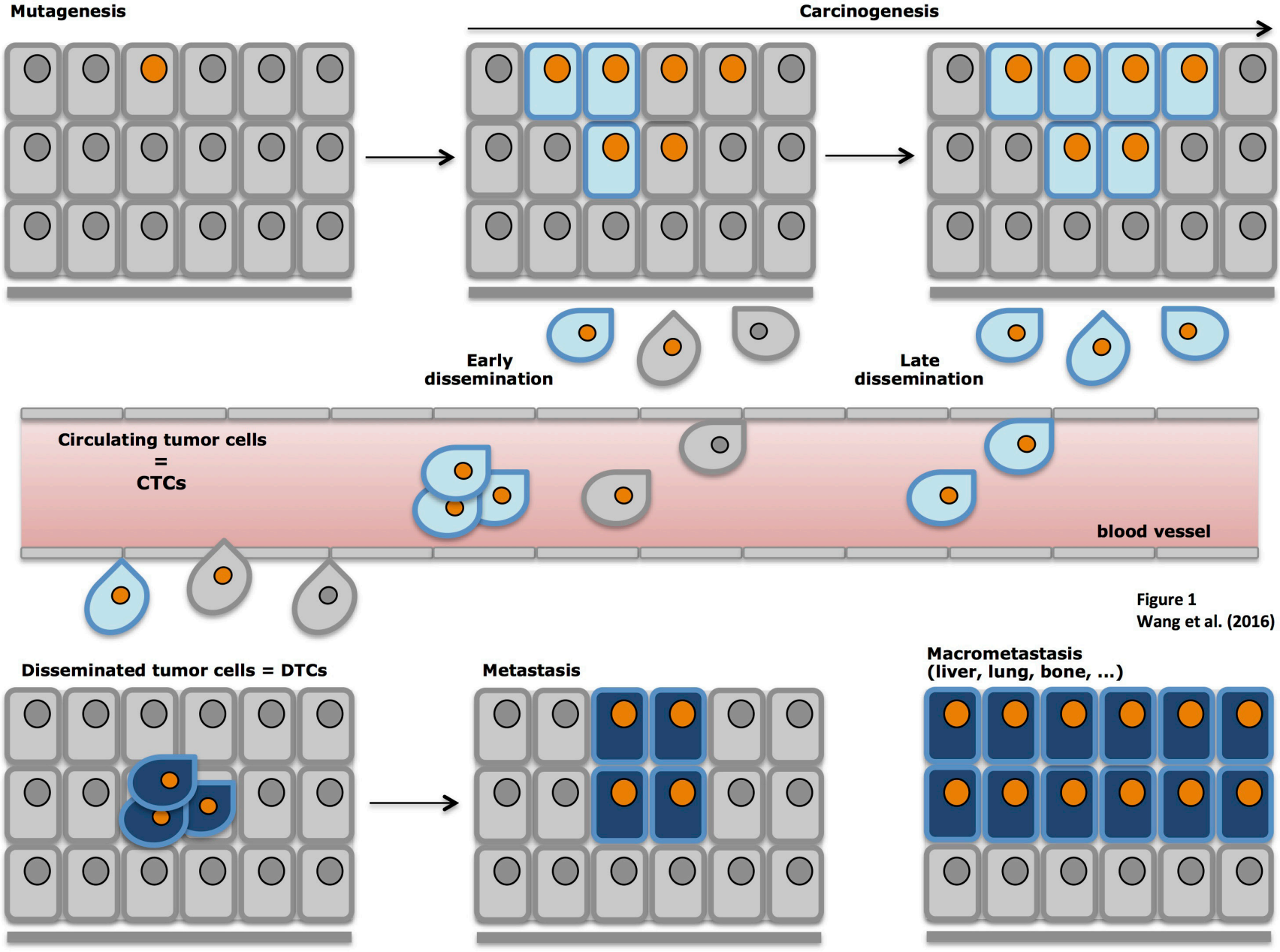

Figure 1: Schematic representation of tumor progression. Primary carcinomas are induced through multiple mutations and the outgrowth of malignant cells in situ. Upon epithelial-to-mesenchymal transition (EMT) cells acquire migratory and invasive traits, detach from primary tumors and locally invade surrounding tissue. In a next step, locally invading cells gain access to blood or lymph vessels through intravasation and become circulating tumor cells (CTCs). After extravasation, CTCs settle in novel organs/sites and are termed disseminated tumor cells (DTCs), which can give rise to micro- and macrometastases in various organs. 
rather have to adapt "on site" in a new micro-environment might be more capable of metastases formation [63, 69, 86]. Whichever theory is eventually correct (most likely both scenarios can occur in cancer patients and can explain the different individual courses of disease), the general assumption is that the process of metastases formation is poorly efficient.

Data on a direct contribution of CTCs and DTCs to metastases formation remains scarce up to now, but the few available data indicate that CTCs and DTCs are indeed metastatic precursors and therefore direct targets for systemic therapy. In breast cancer patients, presence of DTCs at the time point of primary tumor diagnosis or following systemic treatment strongly correlated with metastasis at distant sites $[84,87]$. Proof of a tumorigenic potential of DTCs came from cell lines generated from micrometastatic DTCs from lymph nodes of patients suffering from esophageal cancers, which generated tumors in immune-compromised SCID mice [88]. Direct evidence for a tumorigenic potential of CTCs came from metastatic breast cancer [46] and aggressive small cell lung cancer (SCLC) [89] that is characterized by early dissemination and utterly poor prognosis.

Seminal proof of a metastatic potential of circulating cells was recently published for luminal breast cancer, formally demonstrating the existence of metastasis-initiating cells (MICs) amongst CTCs [46]. Intrafemoral injection of a minimum of $>1,000$ human CTCs into immune-compromised NSG mice induced the development of bone, lung and liver metastases with a latency time to disease of 6-12 months. Taking into account that values of $>5$ CTCs per $7.5 \mathrm{~mL}$ of blood showed prognostic correlation with poor survival of breast cancer, these patients would display an approximated total load of $>3,500$ CTCs in circulation and theoretically surmount thresholds required for metastases formation in mouse models. Obviously these calculations are rough estimations and extrapolate numbers from animal models to human disease. In fact, only four out of 106 patients analyzed complied with the above mentioned requirements of $>1000$ CTCs per injection, out of which CTCs from 3 patients actually generated metastases [46].

Metastatic potential is highly enriched in clusters of CTCs present in the blood of patients. In metastatic breast cancer, oligoclonal clusters are held together through plakoglobin-activated adhesion and harbor $>20$-fold increased metastatic potential compared to single cell CTCs [90]. Hence, metastatic breast cancer CTCs comprise subpopulations with metastatic potential, however efficiency and frequency of MICs appear slight or can not be properly monitored with the current experimental tools.

Subcutaneous xenotransplantation of CTCs from distantly metastasized small-cell lung cancer patients into NOD-SCID-IL2-receptor gamma chain deficient (NSG) mice induced tumor formation. Four out of six samples of
CTCs generated palpable tumors in a time range of 2.4-4.4 months and reflected the patient's response to platinum and etoposide [89]. Numbers of CTCs inoculated $(20-1,625)$ correlated with the time to generate palpable tumors and $>400 \mathrm{CTCs}$ per $7.5 \mathrm{~mL}$ of blood were required for tumor formation in xenotransplants. Additionally, circulating tumor cell-derived xenografts (CDX) from SCLC also induced the formation of distant metastases in lungs and brains of mice, hence demonstrating a metastatic potential. Importantly, CTCs and CDXs from individual patients shared genomic alterations, but displayed intratumoral and especially intertumoral heterogeneity [89]. Such heterogeneity is clinically relevant given its impact on treatment, chemoresistance, dissemination and metastases formation in breast cancer $[24,25]$ and non-small cell lung cancer [91].

The abovementioned studies demonstrated formally that CTCs are tumorigenic and metastatic, confirming the assumed importance of CTCs in disease progression. Because CTCs can preserve morphological and genetic characteristics of primary tumors and faithfully recapitulate responses of donor patients to chemotherapeutic agents, they represent a means to develop precision medicine strategies based on routinely monitoring molecular features of CTCs. In this context, CDXs become a major tendency as an alternative to PDXs, especially when tumors were inaccessible or difficult to biopsy [92].

It appears sensible to consider targeting of CTCs as a reservoir for MICs, but formal proof of the existence and metastatic potential of MICs is required for additional tumor entities to fortify this concept. Targeting CTCs/ DTCs as precursors of metastases might be further complicated by plasticity and substantial heterogeneity observed not only in primary tumors but also in systemic cancer cells [25, 89, 93-98]. Metastatic potential could either be inherent to subclones of cells present in the primary tumor and/or be acquired by subsets of cells through mutations, epigenetic and transcriptional modeling of gene expression profiles $[62,68,85,99$, 100], even at very early disease stages [61]. From a therapeutic point of view, targeting of CTCs and DTCs should concentrate on subsets with (regained) proliferative capacity as targets of chemotherapy and adjuvant immunetherapy. Here, the actual presence of target antigens for therapeutic antibodies must be thoroughly evaluated. In a second approach, induction of exit of dormancy in order to achieve sensitization for chemo- and radiotherapy [101] and inhibition of the switch from dormancy to proliferation [102] are valuable approaches to inhibit the outgrowth of MICs [103-106]. In this respect, it is of interest that the microenvironment present in bone marrow contributes to the regulation of tumorigenic traits, either silencing tumor cells into dormancy or re-activating them to circulate and proliferate. In breast cancer, tumor dormancy can be observed even up to decades before the 

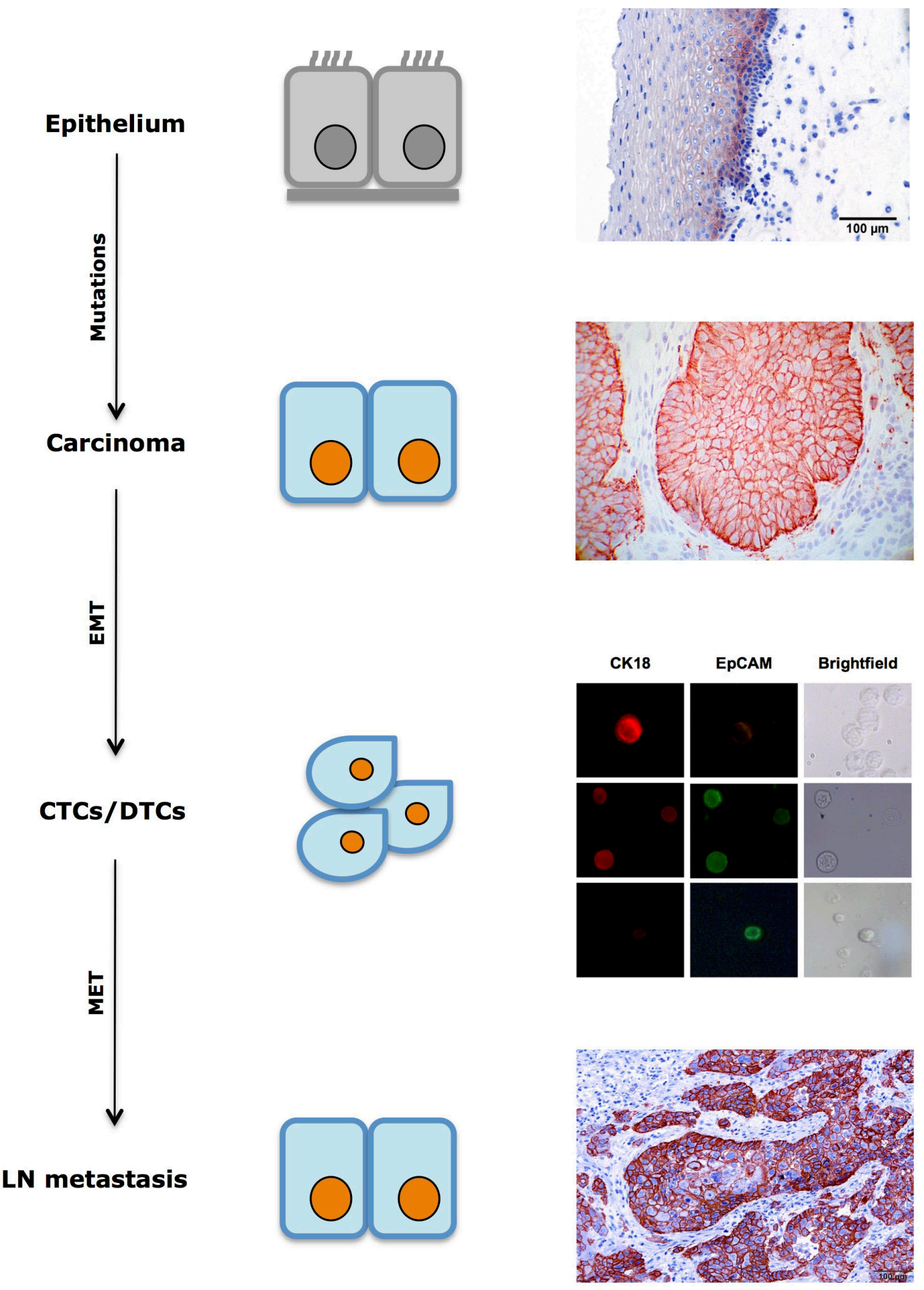

Figure 2: Dynamic expression of EpCAM in tumor progression. EpCAM expression in normal mucosa is commonly restricted to cells of the suprabasal layers. During tumor formation through sequential mutations, EpCAM expression is frequently increased in cells of primary carcinomas. Circulating and disseminated tumor cells (CTCs/DTCs) display mixed expression patterns with retained or lost expression of EpCAM. Macrometastases is often characterized by strong expression of EpCAM, which is similar to the corresponding primary tumor. DTC immunofluorescence pictures displaying EpCAM status were taken with permission from [10]. 
outgrowth of overt metastases. For example, perivascular endothelial cells induce dormancy of breast cancer cells through the release of thrombospondin 1, whereas sprouting neo-vasculature accelerates cancer cell growth [106]. Hence, understanding initiation and regulation of tumor dormancy is yet another level of complexity and probably the furthest away from clinical application.

\section{DIRECT ANALYSIS OF SYSTEMIC CANCER FOR EFFICIENT TREATMENT}

Molecular targets for cancer such as HER2, EGFR, EpCAM, VEGF, amongst others, have been defined in primary tumors and, selectively, in systemic cancer cells (Table 1). However, most cancers show marked intra- and inter-patient heterogeneity due to evolution of different clones and evolutionary changes to adapt to novel microenvironments [96, 99, 107-110]. As a result, measurement of molecular targets in primary tumors is insufficient to predict efficacy of adjuvant therapies because expression patterns in primary tumors are not systematically conforming those of CTCs and DTCs [111, 112]. Despite a frequent resemblance of antigen profile between primary tumors and metastases [113, 114], differences in gene and protein expression occur [115118]. Breast cancer metastatic cells have for example been shown to re-express E-cadherin and catenins as opposed to the cognate primary tumors [116]. As a result, antigenpositive primary tumors can give rise to antigen-negative CTCs and DTCs, and vice versa, or to the expression of mutated antigen variants as was shown for EGFR and HER2 [10, 11, 13, 25, 35, 119-121]. Hence, patients with antigen-positive primary tumors might remain unaffected by antibody therapy owing to a lack of antigen on CTCs and/or DTCs, while patients with antigen-negative primary tumors but antigen-positive CTCs and/or DTCs will not be quoted as eligible for therapy. Thus, analysis of molecular markers should be conducted in primary tumors and repeatedly in liquid biopsies to thoroughly support decisions on therapeutic approaches. Optimally, a panel of markers with associated therapeutic agents should be included in such analyses. Beyond that, unbiased molecular characterization of CTCs, DTCs and metastases at the genetic and protein level will help to find new targets for improved therapy of systemic cancer [14-16, 19, 21, $48,51,52,54,57,58,64,67,68,71,73,85,86,109$, 122-128]. However, it must be noted that the technical requirements for the application of comprehensive liquid

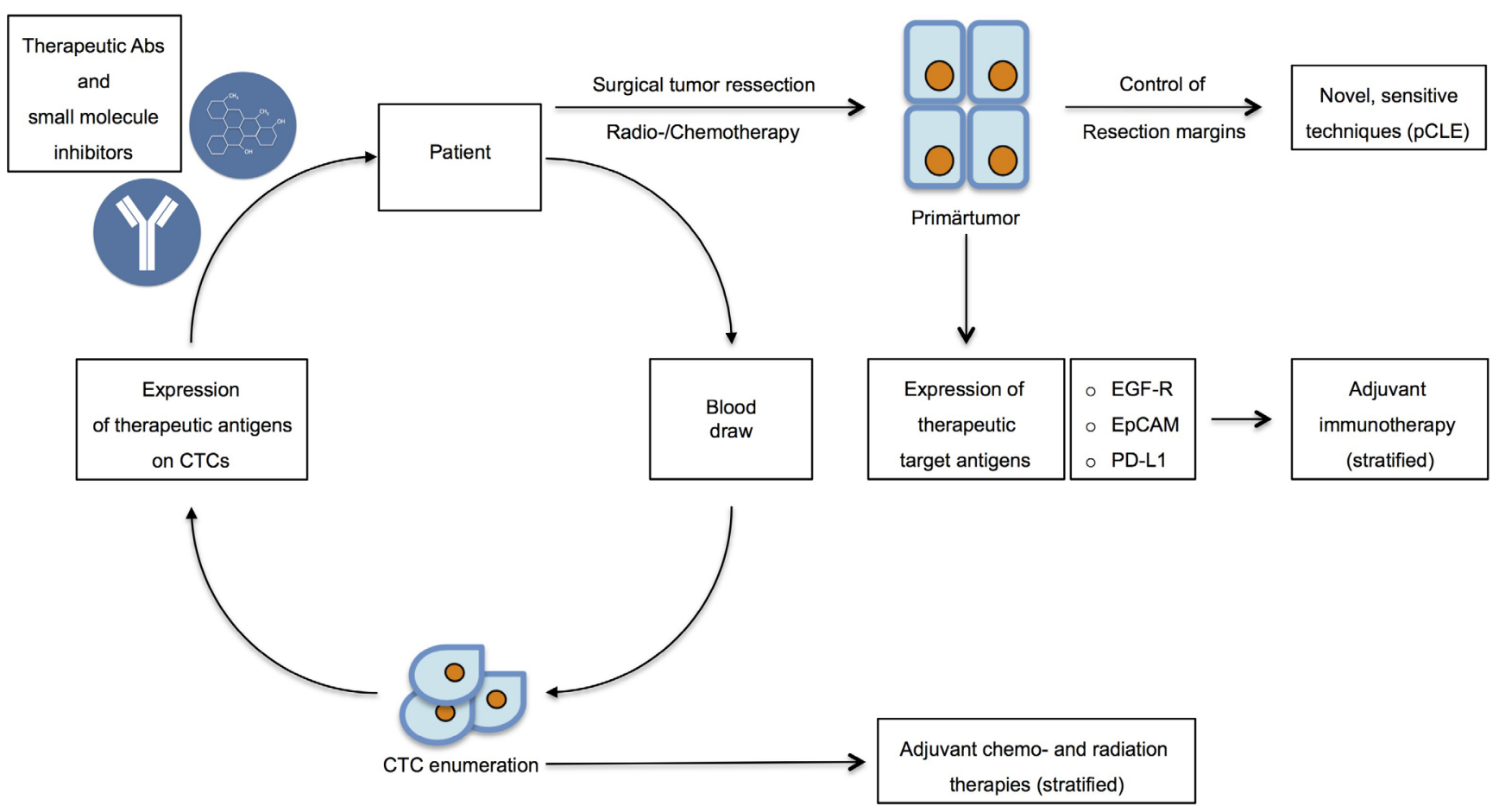

Figure 3: Therapeutic options in targeting CTCs and DTCs. After initial diagnosis, patients eligible for operation undergo surgical resection of the primary tumors in combination with chemo- and radiation therapy. Resection margins should be controlled through novel, sensitive techniques including probe-based confocal laser endomicroscopy (pCLE) to assure complete withdrawal of tumors. Routinely, the expression of therapeutic target antigens such as e.g. EGFR, EpCAM and PD-L1 should be assessed in order to improve adjuvant therapy through adequate stratification. Simultaneously, blood draws will serve to assess CTC numbers and to perform molecular characterization of the expression of therapeutic antigens. CTC enumeration will be implemented into decisions concerning adjuvant chemo- and radiation therapies. Molecular profiling of CTCs will allow for the determination of the application of novel therapeutic antibodies and small molecule inhibitors. 
biopsies in clinical routine, especially in the adjuvant situation with all its restrictions, are not yet achieved.

\section{CURRENT MOLECULAR TARGETS}

A recent analysis of cell surface markers of metastatic breast cancer-derived MICs as described by Baccelli et al. revealed the expression of epithelial marker EpCAM, hyaluronic acid receptor CD44, integrin associated protein $\mathrm{CD} 47$ and hepatocyte growth factor receptor c-Met as a signature for MICs [46]. EpCAM is generally used as anchor protein to enrich CTCs in various approaches [47, 129], CD44 is a marker for cancer stem cells in numerous tumor entities [130] including breast cancer [131], and is involved in metastases formation $[132,133]$, while CD47 and c-Met had been linked to recurrence and an invasive program of tumor cells [134, 135]. The frequency of CD44/CD47/c-Met triple-positive EpCAM-expressing CTCs increased by almost two-fold following disease progression and numbers of triplepositive CTCs were associated with higher metastatic burden, whereas simple enumeration of EpCAM-positive CTCs was not [46]. Hence, it can be assumed that these markers of breast cancer MICs provide cells with signals required for metastases formation in vivo and thus constitute possible therapeutic targets. A role for these MIC markers in metastases formation is further suggested by their frequent expression and functions in cancer stem cells of various entities [130, 136-140].

In the following, the above mentioned markers as well as additional, classical molecular targets will be discussed in light of their expression and availability on systemic cancer cells.

\section{Epithelial cell adhesion molecule EpCAM}

EpCAM is, to date, the antigen of choice for the enrichment of CTCs out of the blood of patients [141]. The US food and drug administration approved the CellSearch ${ }^{\mathrm{TM}}$ system relies on capturing CTCs via EpCAM-specific antibodies, and subsequent detection of DAPI positive, cytokeratin positive and CD45 negative objects $[47,52,129]$.

Although EpCAM has great value for the capturing of CTCs from the blood of patients, drawbacks relate to its long assumed continuous expression in all phases of tumor progression, including circulating tumor cells. This assumption was based on the alleged constant expression of the molecule in primary tumors and actually represented a best candidate approach to enrich malignant epithelial cells from blood at the time CellSearch ${ }^{\mathrm{TM}}$ was developed. EpCAM displayed epithelial specificity as well as frequent and high expression in numerous carcinomas [142, 143]. However, it is nowadays clear that EpCAM is subject to dynamic changes in expression throughout tumor progression, including changes related to mesenchymal transitions [11]. EMT and its reversion MET emerged as major driving forces that underlie phenotypic changes during tumor progression [107-109, 144] (Figure 1). Despite the knowledge that the expression of typical epithelial markers involved in cell adhesion and proliferation such as E-cadherin $[145,146]$ are lost with the induction of EMT [147-149], the possibility of a dynamic expression of EpCAM surfaced only more recently [11]. In fact, EpCAM can be lost on CTCs of various entities $[12,35,150-153]$ as well as on DTCs [10], and CTCs enumeration might necessitate an upwards revision, as reported recently $[16,35,152,154,155]$. Whereas $15 \%$ of metastatic lung cancer patients displayed $\geq 5$ EpCAMpositive CTCs in $7.5 \mathrm{~mL}$ of blood, the percentage raised to $41 \%$ when taking EpCAM-negative cells into account [150]. Down-regulation or even complete loss of EpCAM in CTCs and DTCs might not only reflect ongoing EMT in these cells. Indeed, EpCAM functions as a central molecule in signaling, migration, regulation of cell cycle progression and tumorigenicity [156-159]. Active loss of EpCAM cell surface expression through endocytosis was seen in cells initiating migration $[10,160,161]$. Further analyses revealed increased migration and invasion of EpCAM-negative/low cancer cells [10, 162], which was however contradictory to reports on increased migration and invasion in the presence of EpCAM [163-166]. EpCAM-positive/high cancer cells were characterized by increased tumorigenicity, enhanced proliferation and diminished sensitivity towards growth factor deprivation $[139,156,158,159,165,167,168]$. Oncogenic potential of EpCAM is initiated via regulated intra-membrane proteolysis that generates a signaling active intracellular domain termed EpICD, which increases transcription of cell cycle and pluripotency regulators $[156,158,160,169$ 172]. Ultimately, EpCAM was recognized as a membrane protein that is strongly overexpressed in cancer stem cells of all major carcinoma entities [136, 137]. A contribution of EpCAM to "cancer stemness" is further conceivable given its capacity to stimulate pluripotency of embryonic stem cells $[171,173]$.

Thus, EpCAM emerged as a switch between traits of epithelial and mesenchymal cells. Interestingly, EpCAM-positive DTCs of esophageal cancer patients strongly associated with lymph node metastases and poor OS, but represented a minority in these patients, with approximately two-thirds bearing EpCAM-negative DTCs [10]. MICs defined in breast cancer patients expressed EpCAM strongly [46], so that EpCAM-positive CTCs constitute therapeutic targets. However, EMT switches were observed in primary tumors of breast cancer patients and even more so in CTCs [25]. Appearance of mesenchymal CTCs (EMT-CTCs) in patients correlated with disease progression and a resistance towards chemotherapy [25, 26]. Similarly, EMT-CTCs correlated with poorer OS in a small cohort of HNSCC patients 
[174], which might be explained by different capacities of epithelial and mesenchymal cancer stem cells in HNSCC [162].

Hence, EpCAM expression on primary tumor cells but also on CTCs might activate proliferation and tumor initiation at distant sites, and is a novel parameter, whose measurement might represent a surrogate for differing phenotypic states of cancer cells (Figure 2). In fact, EpCAM expression is dynamic and not steady as it was long assumed. In this respect, antigen-independent isolation of CTCs and DTCs becomes highly relevant in order to assess and study varying phenotypes of these cells in tumor progression, recurrence, metastases formation and treatment responses. Various recent CTC isolation and/or enrichment technologies have taken this notion into consideration and isolate CTCs through size and filtration separation [39, 175] or upon depletion of hematopoietic cells and assessment of cellular ploidy, as well as tumor biomarker expression [176, 177]. The later technique termed with iFISH combines the determination of polyploid tumor cells using chromosome enumeration probes with phenotypic immunofluorescence detection of markers of choice. Diversified subsets of CTCs or DTCs may possess distinct clinical significance in terms of drug resistance, cancer metastases and disease relapse [178].

Knowledge of EpCAM expression on CTCs and DTCs in the bone marrow could reveal of clinical and therapeutic importance, since existing monoclonal and recombinant antibodies (Panorex, MT201, MT101, ING1) might experience a revival for the systemic targeting of tumorigenic CTCs and DTCs. Furthermore, small molecule inhibitors of EpCAM signaling addressing its cleavage could be envisaged in combinatorial therapies. Last but not least, determination of the epithelial versus mesenchymal status of CTCs and DTCs might represent a surrogate marker for therapy response and recurrence [25], which could be repeatedly assessed in peripheral blood in clinical routine.

\section{EPIDERMAL GROWTH FACTOR RECEPTOR 2 HER2}

HER2 has become a central therapeutic target. Treatment with monoclonal antibodies or small molecules is currently a routine intervention for metastatic breast cancer patients expressing high levels of HER2 in primary tumor cells as measured upon the HercepTest ${ }^{\text {TM }}$. HER2 is a receptor tyrosine kinase involved in regulation of cell proliferation and apoptosis via MAP-kinases, PI3/ AKT and the mTOR pathway [179-184]. Opsonization of HER2-positive cells and functional inhibition of HER2 with therapeutic antibodies and small molecule inhibitors proved beneficial for node-negative and -positive as well as metastatic breast cancer patients [9, 185, 186]. HER $2^{\text {high }}$ patients treated with Trastuzumab displayed a $12 \%$ increase in OS and a $33 \%$ reduction of the risk of death [186]. Owing to the longest history and most comprehensive knowledge [187], the impact of HER2 expression on CTCs with respect to disease outcome, as well as a benefit from anti-HER2 therapy for patients with HER2-positive CTCs were assessed. The prognostic value for the presence of CTCs with respect to OS was confirmed and stratification according to HER2 expression on CTCs was performed. Cut-off was set at $>30 \%$ of CTCs expressing HER2, which clearly correlated with response to treatment. Patients undergoing anti-HER2 treatment and bearing HER2-postive CTCs had significantly prolonged progression-free survival (8.8 versus 2.5 months) [188]. Furthermore, anti-HER2 treatment was efficient since patients bearing HER2-positive CTCs but left untreated had a very poor progression-free disease (1.5 versus 8.8 months) [188].

Potential benefit of targeting HER2-positive CTCs in patients is further addressed in the DETECT III study (NCT01619111). In this ongoing multi-center, randomized phase III study, metastatic breast cancer patients with initially HER2-negative primary tumors but HER2positive CTCs are treated with standard therapy alone or standard therapy combined with Lapatinib treatment (antiHER2/EGFR inhibitor). 711 out of 1123 HER2-negative patients enrolled in this study had measurable CTCs counts after EpCAM-mediated enrichment, and 134 patients had at least one HER2-positive CTCs in $7.5 \mathrm{~mL}$ blood. This represents a percentage of discordance of primary tumor versus CTCs of $18.8 \%$. Other research groups similarly reported on such discordance in expression profiles [12-14, 189]. Stratification of patients into subgroups demonstrated a strong and significant association of HER2-positive CTCs with hormone receptor-positive and lobular breast cancer. Assessment of the efficacy of Lapatinib treatment in addition to standard care is ongoing and highly anticipated.

Hence, anti-HER2 therapy, which is already in clinical routine for breast cancer patients, clearly demonstrated the power of molecular analysis and targeting of CTCs in the control of metastatic disease and is very encouraging.

\section{Epidermal growth factor receptor EGFR}

EGFR is, similarly to HER2, a major target for targeted therapies via monoclonal antibodies and inhibitors [190], which belongs to the same receptor tyrosine kinase family [191-194]. In fact, EGFR is the founding member of this family of signaling receptors, which was discovered in 1978 [195]. EGFR signaling is broad and comprises differential activation modes through ligand induced phosphorylation and interaction with a multitude of intracellular pathways such as MAP-kinases, phospholipase C, phosphatidyl-inositol-3 phosphate kinase, small GTPases, and JAK/STATs [193, 196, 197]. Thereby, EGFR activation stimulates 
proliferation, migration, angiogenesis, differentiation, survival, cancer formation and progression [198, 199]. Besides classical signaling via phosphorylation-induced activation of downstream targets, EGFR was demonstrated to translocate into the nucleus and to activate transcription through association with target gene promoters [200-203]. Additionally, EGFR is subject to proteolytic cleavage at the membrane by members of the metalloproteinase and/ or rhomboid protease family to generate an intracellular domain (ICD), the actual function of which remains undescribed [204-206].

Since anti-EGFR antibodies are part of late stage therapies, the status of EGFR-positive CTCs was assessed with the purpose to measure therapy responses to Cetuximab and to inquire a potential use of EGFR therapeutic antibodies for the eradication of CTCs [207209]. In colorectal cancer patients, great intra- and interpatient heterogeneity was observed at the level of EGFR expression and mutation status, which might explain differences in treatment responses [207]. Although intrapatient variance represents an issue, the actual expression of EGFR on CTCs consolidates the strategy of CTCs targeting through biological and small molecule inhibitors already available on the market. Current research though focuses on the detection of EGFR mutations in CTCs and ctDNA, as surrogate markers for monitoring purposes rather than stratification means for subsequent anti-EGFR therapies. These efforts have peaked in the launch of a specific test of EGFR mutation in ctDNA called Selector ${ }^{\mathrm{TM}}$. Additional studies reporting on steady expression levels of EGFR in breast cancer patient-derived CTCs [210], as well as an eradication of EGFR-positive and -negative CTCs following gefitinib treatment [211], further support the concept of antigen-specific targeting of CTCs. However, remaining CTCs in these breast cancer patients revealed negative for EGFR, which pinpoints at possible escape mechanisms that could be addressed through the use of multiple targeted treatments. Furthermore, radiotherapy reportedly increased numbers of EGFR-positive CTCs in locally advanced head and neck squamous cell carcinomas (HNSCC), which could be counteracted upon treatment with anti-EGFR antibody Cetuximab [32]. EGFR was associated with an EMT phenotype of non-metastatic breast cancer patients' CTCs, which co-expressed markers of mesenchymal cells such as vimentin and slug [212]. Hence, although somewhat unexpected, EGFR might be a positive regulator of EMT processes observed in subsets of CTCs, which are selected upon radiotherapy. However, numbers of HNSCC patients enrolled in CTC enumeration and EGFR evaluation was comparably small $(n=31)$ and further validation in larger cohorts is necessary.

Comparably to HER2, anti-EGFR antibodies and small molecule inhibitors are approved for clinical use for colorectal, head and neck squamous cell carcinomas (HNSCC) and non-small cell lung cancer. Both, HER2 and
EGFR are therefore interesting targets to therapeutically address systemic disease that have already proven beneficial for cancer patients. Even more so, a combination of HER2- and EGFR-specific drugs appears valid since HER2 signaling emerged as one major route of resistance to Cetuximab, suggesting that Trastuzumab or equivalents could help overcoming resistance [213].

\section{Hyaluronic acid receptor CD44}

CD44 in fact designates a family of more than 20 differing transmembrane proteins that are generated from the single $C D 44$ gene through extensive alternative splicing of 10 out of 20 exons, as well as post-translational modifications [214-216]. CD44 has multiple functions in adhesion to extracellular matrix, cytokines and growth factors presentation, migration and differentiation, cell and nuclear signaling [217-223]. Early on, expression of splice variants of CD44 such as CD44v6 was shown to stimulate metastases formation and was in the focus of cancer research [132, 133, 224, 225]. Further interest arose with the description of CD44 as a marker for cancer stem cells in various carcinoma entities including breast [131], colon [226], hepatocellular carcinomas [227], head and neck [228], lung and pancreatic cancers [229, 230]. Reasons for this recurrent expression of CD44 in tumor initiating cells of various malignancies including hematopoietic and epithelial cancers have been reviewed in depth and relate to the various roles mentioned above [130]. Eventually, CD44 must be considered as a signaling platform, which not only activates cell adhesion and migration through binding of ECM components, but also on proliferation, apoptosis, angiogenesis, differentiation and regulation of stemness through the activation of multiple pathways such as Wnt/ß-catenin, NF- $\kappa \mathrm{B}$, Src and PKC kinases, Rho GTPases [130, 138, 231]. As such, CD44 enables cells to react and respond to cues from the microenvironment, inducing a stem cell phenotype including the expression of stemness factors and the regulation of traits of metastatic cells [220, 221].

In their seminal work on MICs in breast cancer, Baccelli et al. provided the first translation of markers of cancer stem cells to a subpopulation of metastasesinducing CTCs, thus providing a MICs signature [46]. They combined the function of CD44 in metastases formation with its strong and frequent expression on CSCs to demonstrate for the first time the presence of CD44 on MICs. Thereby, CD44 became a potential target candidate for the eradication of MICs upon adjuvant therapies comprised of CD44-specific antibodies. Approaches to target acute myeloid leukemia cells using the monoclonal pan-CD44 antibody H90 proved very efficient [232], and might give a basis for future application in the eradication of MICs. However, given the potential of CD44-specific antibodies to target antigen-positive hematopoietic cells, knowledge of splice variants preferentially expressed on 
CTCs, and especially on MICs, would help designing therapeutics with an effectiveness more restricted to CTCs. In this respect, the expression of a sialofucosylated glycoform of CD44 termed HCELL for hematopoietic cell E/L-selectin ligand on tumor cells is of great interest. HCELL is a major ligand for both selectin subtypes, which allows the interaction of tumor cells with endothelium, leukocytes and platelets and might thus trigger intra- and extravasation of CTCs in and out of vessels during tumor progression [233, 234]. Therapeutic blockage of HCELL on CTCs, given its expression, would represent an elegant way to prevent dissemination and metastases formation.

In homology to EpCAM, HER2, and EGFR, all attempts to target CD44 on CTCs will depend on thorough knowledge of expression profiles. Thus, future clinical studies should optimally implement measurements of CD44 expression on CTCs.

\section{Hepatocyte growth factor receptor c-Met and Integrin-associated protein CD47}

cMet and CD47 are emerging markers of importance owing to their capacity to foster migration and invasion [135] and control cells of the innate immune system [235], respectively. Luminal breast cancer patients harboring cMet/CD47-positive CTCs were at high risk of metastatic spread. Accordingly, double-positive CTCs displayed substantial ability to develop metastases in mouse models $[78,236]$. The CellSearch ${ }^{\mathrm{TM}}$ platform was modified to enrich for c-Met-positive CTCs, which were rare according to this study and might restrain the use of inhibitory monoclonal antibodies and inhibitors that are currently in clinical testing [237, 238] (http:// meetinglibrary.asco.org/content/140112-158). Besides MICs in breast cancer, CD47 was strongly expressed on CTCs from colorectal cancer patients and might act as antagonist of innate immune cells during circulation [239, 240]. Hence, CD47 and c-Met are of great interest for therapeutic targeting of systemic cancer, but clearly require more in-depth analysis of expression and function on CTCs to warrant therapeutic addressing.

\section{Programmed cell death protein 1 PD-1 and its ligand PD-L1}

PD1 and PD-L1 is a receptor-ligand pair of membrane proteins expressed on immune cells ( $T, B$, macrophages, natural killer and myeloid cells), endothelial and epithelial cells [241]. Activation of PD-1/PD-L1 signaling results in immune suppression through inhibition of ZAP70 and protein kinase C variants in T cells [242244]. PD-L1 is increased in carcinoma cells of numerous entities, and, as such, enables tumor cells to dampen activated $\mathrm{T}$ cell responses, thereby initiating cancer immune evasion [241, 245, 246]. Accordingly, expression of components of the PD-1/PD-L1 axis, also termed PD pathway, correlated with poor prognosis and survival of carcinoma patients [247]. Therapeutic inhibition of the PD pathway displayed great potential to reactivate immune cells and induce long-lasting remissions [244, 248, 249]. Thus, PD treatment represents one of the most promising cancer therapies of the moment [241, 250-252], with checkpoint inhibitors comprising both, PD-1 and PDL1 targeting therapeutic antibodies in clinical trials (see Tables 1-4 in [252]).

Importantly, PD-L1 expression was demonstrated on CTCs in various carcinoma entities including breast [253, 254], oral [255], colorectal and prostate [256], lung cancer (http://meeting.ascopubs.org/cgi/content/ abstract/34/15 suppl/e23036). Interestingly, Satelli et al. used the cell-surface vimentin (CSV)-specific antibody to isolate EMT-CTCs and demonstrated differing subcellular localization of PD-L1. Nuclear localization of PD-L1 in EMT-CTCs was associated with poor prognosis of colorectal and prostate cancer patients [256]. For the case of ovarian cancer, expression of PD-L1 in primary tumors correlated with peritoneal dissemination and the generation of ascites, suggesting a role for PD-L1 in the inhibition of cytotoxic T cells and dissemination, which was confirmed in mouse models [257].

Hence, PD-L1 expression on CTCs has once more dual potential for the identification of patients likely to respond to $\mathrm{PD}$ treatment in the context of liquid biopsies and as therapeutic target to reactivate the immune system towards systemic cancer cells.

\section{CONCLUSIONS}

Metastasis is the major thread for cancer patients and, despite progress in the era of molecular therapy, remains incurable in most cases. Surgical options for the removal of metastases are limited and systemic treatment has been so far rather ineffective. Research on molecular mechanisms involved in metastases formation suggested a central role of circulating and disseminated tumor cells. The majority of evidence supports the notion that CTCbased molecular analysis has the potential to provide real-time and non-invasive surrogates to enable better diagnostics, prognostication, and prediction. Subsets of CTCs expressing cell surface markers EpCAM, CD44, CD47 and c-Met were capable of initiating metastases in animal models [46] and hence, these seminal findings might pave the way for novel strategies in cancer therapy because potential targets of therapy, both cellular and molecular, become apparent (Figure 3). It must however be noted that a formal proof of the metastatic capacity of CTCs subpopulations has to the best of our knowledge only been given for metastatic breast cancer and small cell lung cancer, and is thus lacking for other entities.

Currently, cancer patients are eligible for adjuvant therapies targeting cell surface antigens such as HER2 and 
EGFR, primarily in late stages of disease, when metastases have already developed or tumors relapsed. Clinical interventions might profit from monitoring CTCs and the repeated analyses of the expression of molecular targets such as HER2, EGFR, EpCAM and PD-L1 on CTCs during the course of targeted therapies. Based on these analyses, early application of therapeutic agents targeting markers on MICs could be considered and clinically addressed. A basic requirement is to have reliable assays at hand that deliver such data. In view of the plethora of promising available assays, it is therefore of utmost importance to standardize and validate such assays. This is currently addressed for lung cancer and a breast cancer subtype by a large EU/IMI consortium (www.cancer-id. eu). Similar initiatives must be extended to other cancer types and, especially, to the adjuvant situation.

\section{CONFLICTS OF INTEREST}

Peter P. Lin is president at Cytelligen Inc. He does not own company shares. The authors have no further conflict of interest to disclose.

\section{GRANT SUPPORT}

Work was supported by the Wilhelm-SanderStiftung (project \#2015.019.1 to OG) and the Deutsche Forschungsgemeinschaft (DFG GI540-3/1 to OG).

N.H. Stoecklein receives support from CANCERID, an Innovative Medicines Initiative Joint Undertaking under grant agreement no. 115749, resources of which are composed of financial contribution from the European Union's Seventh Framework Program (FP7/2007-2013) and EFPIA companies' in-kind contribution.

\section{REFERENCES}

1. Talmadge JE, Fidler IJ. AACR centennial series: the biology of cancer metastasis: historical perspective. Cancer Res. 2010; 70: 5649-69. doi: 10.1158/0008-5472.CAN-101040.

2. Scott AM, Wolchok JD, Old LJ. Antibody therapy of cancer. Nat Rev Cancer. 2012; 12: 278-87. doi: 10.1038/ nrc3236.

3. Wu P, Nielsen TE, Clausen MH. FDA-approved smallmolecule kinase inhibitors. Trends Pharmacol Sci. 2015; 36: 422-39. doi: 10.1016/j.tips.2015.04.005.

4. Wu P, Nielsen TE, Clausen MH. Small-molecule kinase inhibitors: an analysis of FDA-approved drugs. Drug Discov Today. 2016; 21: 5-10. doi: 10.1016/j.drudis.2015.07.008.

5. Kurtz JE, Dufour P. Adecatumumab: an antiEpCAM monoclonal antibody, from the bench to the bedside. Expert Opin Biol Ther. 2010; 10: 951-8. doi: 10.1517/14712598.2010.482098.
6. Tolaney SM, Barry WT, Dang CT, Yardley DA, Moy B, Marcom PK, Albain KS, Rugo HS, Ellis M, Shapira I, Wolff AC, Carey LA, Overmoyer BA, et al. Adjuvant paclitaxel and trastuzumab for node-negative, HER2-positive breast cancer. N Engl J Med. 2015; 372: 134-41. doi: 10.1056/ NEJMoa1406281.

7. Piccart-Gebhart MJ. Moving away from the "one shoe fits all" strategy: the key to future progress in chemotherapy. J Clin Oncol. 2005; 23: 1611-3. doi: 10.1200/ JCO.2005.01.007.

8. Piccart-Gebhart MJ, Procter M, Leyland-Jones B, Goldhirsch A, Untch M, Smith I, Gianni L, Baselga J, Bell R, Jackisch C, Cameron D, Dowsett M, Barrios CH, et al. Trastuzumab after adjuvant chemotherapy in HER2positive breast cancer. N Engl J Med. 2005; 353: 1659-72. doi: 10.1056/NEJMoa052306.

9. Puglisi F, Piccart M. Trastuzumab and breast cancer. Are we just beyond the prologue of a fascinating story? Onkologie. 2005; 28: 547-9. doi: 10.1159/000088849.

10. Driemel C, Kremling H, Schumacher S, Will D, Wolters J, Lindenlauf N, Mack B, Baldus SA, Hoya V, Pietsch JM, Panagiotidou P, Raba K, Vay C, et al. Contextdependent adaption of EpCAM expression in early systemic esophageal cancer. Oncogene. 2013. doi: 10.1038/ onc.2013.441.

11. Gires O, Stoecklein NH. Dynamic EpCAM expression on circulating and disseminating tumor cells: causes and consequences. Cell Mol Life Sci. 2014. doi: 10.1007/ s00018-014-1693-1.

12. Punnoose EA, Atwal SK, Spoerke JM, Savage H, Pandita A, Yeh RF, Pirzkall A, Fine BM, Amler LC, Chen DS, Lackner MR. Molecular biomarker analyses using circulating tumor cells. PLoS One. 2010; 5: e12517. doi: 10.1371/journal.pone.0012517.

13. Meng S, Tripathy D, Shete S, Ashfaq R, Haley B, Perkins S, Beitsch P, Khan A, Euhus D, Osborne C, Frenkel E, Hoover S, Leitch M, et al. HER-2 gene amplification can be acquired as breast cancer progresses. Proc Natl Acad Sci U S A. 2004; 101: 9393-8. doi: 10.1073/pnas.0402993101.

14. Hayes DF, Walker TM, Singh B, Vitetta ES, Uhr JW, Gross S, Rao C, Doyle GV, Terstappen LW. Monitoring expression of HER-2 on circulating epithelial cells in patients with advanced breast cancer. Int J Oncol. 2002; 21: 1111-7.

15. Stoecklein NH, Fischer JC, Niederacher D, Terstappen LW. Challenges for CTC-based liquid biopsies: low CTC frequency and diagnostic leukapheresis as a potential solution. Expert Rev Mol Diagn. 2015: 1-18. doi: 10.1586/14737159.2016.1123095.

16. Joosse SA, Gorges TM, Pantel K. Biology, detection, and clinical implications of circulating tumor cells. EMBO Mol Med. 2015; 7: 1-11. doi: 10.15252/emmm.201303698.

17. Leversha MA, Han J, Asgari Z, Danila DC, Lin O, Gonzalez-Espinoza R, Anand A, Lilja H, Heller G, Fleisher 
M, Scher HI. Fluorescence in situ hybridization analysis of circulating tumor cells in metastatic prostate cancer. Clin Cancer Res. 2009; 15: 2091-7. doi: 10.1158/1078-0432. CCR-08-2036.

18. Riethdorf S, Pantel K. Advancing personalized cancer therapy by detection and characterization of circulating carcinoma cells. Ann N Y Acad Sci. 2010; 1210: 66-77. doi: 10.1111/j.1749-6632.2010.05779.x.

19. Pantel K, Alix-Panabieres C. Real-time liquid biopsy in cancer patients: fact or fiction? Cancer Res. 2013; 73: 63848. doi: 10.1158/0008-5472.CAN-13-2030.

20. Wan L, Pantel K, Kang Y. Tumor metastasis: moving new biological insights into the clinic. Nat Med. 2013; 19: 145064. doi: $10.1038 / \mathrm{nm} .3391$.

21. Janni W, Rack B, Terstappen LW, Pierga JY, Taran FA, Fehm T, Hall C, de Groot M, Bidard FC, Friedl TW, Fasching PA, Brucker SY, Pantel K, et al. Pooled Analysis of the Prognostic Relevance of Circulating Tumor Cells in Primary Breast Cancer. Clin Cancer Res. 2016. doi: 10.1158/1078-0432.CCR-15-1603.

22. Klein CA. Cancer. The metastasis cascade. Science. 2008; 321: 1785-7. doi: 321/5897/1785 [pii]10.1126/ science. 1164853 .

23. Khoo BL, Lee SC, Kumar P, Tan TZ, Warkiani ME, Ow SG, Nandi S, Lim CT, Thiery JP. Short-term expansion of breast circulating cancer cells predicts response to anti-cancer therapy. Oncotarget. 2015; 6: 15578-93. doi: 10.18632/oncotarget.3903.

24. Yu M, Bardia A, Aceto N, Bersani F, Madden MW, Donaldson MC, Desai R, Zhu H, Comaills V, Zheng Z, Wittner BS, Stojanov P, Brachtel E, et al. Cancer therapy. Ex vivo culture of circulating breast tumor cells for individualized testing of drug susceptibility. Science. 2014; 345: 216-20. doi: 10.1126/science. 1253533.

25. Yu M, Bardia A, Wittner BS, Stott SL, Smas ME, Ting DT, Isakoff SJ, Ciciliano JC, Wells MN, Shah AM, Concannon $\mathrm{KF}$, Donaldson MC, Sequist LV, et al. Circulating breast tumor cells exhibit dynamic changes in epithelial and mesenchymal composition. Science. 2013; 339: 580-4. doi: 10.1126/science.1228522.

26. Fischer KR, Durrans A, Lee S, Sheng J, Li F, Wong ST, Choi H, El Rayes T, Ryu S, Troeger J, Schwabe RF, Vahdat LT, Altorki NK, et al. Epithelial-to-mesenchymal transition is not required for lung metastasis but contributes to chemoresistance. Nature. 2015; 527: 472-6. doi: 10.1038/ nature 15748 .

27. Zheng X, Carstens JL, Kim J, Scheible M, Kaye J, Sugimoto H, Wu CC, LeBleu VS, Kalluri R. Epithelial-tomesenchymal transition is dispensable for metastasis but induces chemoresistance in pancreatic cancer. Nature. 2015; 527: 525-30. doi: 10.1038/nature16064.

28. Miyamoto DT, Lee RJ, Stott SL, Ting DT, Wittner BS, Ulman M, Smas ME, Lord JB, Brannigan BW, Trautwein J, Bander NH, Wu CL, Sequist LV, et al. Androgen receptor signaling in circulating tumor cells as a marker of hormonally responsive prostate cancer. Cancer Discov. 2012; 2: 995-1003. doi: 10.1158/2159-8290.CD-12-0222.

29. Bork U, Rahbari NN, Scholch S, Reissfelder C, Kahlert C, Buchler MW, Weitz J, Koch M. Circulating tumour cells and outcome in non-metastatic colorectal cancer: a prospective study. Br J Cancer. 2015; 112: 1306-13. doi: 10.1038/bjc.2015.88.

30. Pecqueux M, Fritzmann J, Adamu M, Thorlund K, Kahlert C, Reissfelder C, Weitz J, Rahbari NN. Free intraperitoneal tumor cells and outcome in gastric cancer patients: a systematic review and meta-analysis. Oncotarget. 2015; 6: 35564-78. doi: 10.18632/oncotarget.5595.

31. Rahbari NN, Bork U, Motschall E, Thorlund K, Buchler MW, Koch M, Weitz J. Molecular detection of tumor cells in regional lymph nodes is associated with disease recurrence and poor survival in node-negative colorectal cancer: a systematic review and meta-analysis. J Clin Oncol. 2012; 30: 60-70. doi: 10.1200/JCO.2011.36.9504.

32. Tinhofer I, Hristozova T, Stromberger C, Keilhoiz U, Budach V. Monitoring of circulating tumor cells and their expression of EGFR/phospho-EGFR during combined radiotherapy regimens in locally advanced squamous cell carcinoma of the head and neck. Int J Radiat Oncol Biol Phys. 2012; 83: e685-90. doi: 10.1016/j.ijrobp.2012.02.009.

33. Tinhofer I, Konschak R, Stromberger C, Raguse JD, Dreyer JH, Johrens K, Keilholz U, Budach V. Detection of circulating tumor cells for prediction of recurrence after adjuvant chemoradiation in locally advanced squamous cell carcinoma of the head and neck. Ann Oncol. 2014; 25: 2042-7. doi: 10.1093/annonc/mdu271.

34. Smerage JB, Barlow WE, Hortobagyi GN, Winer EP, Leyland-Jones B, Srkalovic G, Tejwani S, Schott AF, O'Rourke MA, Lew DL, Doyle GV, Gralow JR, Livingston $\mathrm{RB}$, et al. Circulating tumor cells and response to chemotherapy in metastatic breast cancer: SWOG S0500. J Clin Oncol. 2014; 32: 3483-9. doi: 10.1200/ JCO.2014.56.2561.

35. Gorges TM, Tinhofer I, Drosch M, Rose L, Zollner TM, Krahn T, von Ahsen O. Circulating tumour cells escape from EpCAM-based detection due to epithelial-tomesenchymal transition. BMC Cancer. 2012; 12: 178. doi: 1471-2407-12-178 [pii]10.1186/1471-2407-12-178.

36. Hanssen A, Wagner J, Gorges TM, Taenzer A, Uzunoglu FG, Driemel C, Stoecklein NH, Knoefel WT, Angenendt S, Hauch S, Atanackovic D, Loges S, Riethdorf S, et al. Characterization of different CTC subpopulations in nonsmall cell lung cancer. Sci Rep. 2016; 6: 28010. doi: 10.1038/srep28010.

37. Ignatiadis M, Rack B, Rothe F, Riethdorf S, Decraene C, Bonnefoi H, Dittrich C, Messina C, Beauvois M, Trapp E, Goulioti T, Tryfonidis K, Pantel K, et al. Liquid biopsybased clinical research in early breast cancer: The EORTC 90091-10093 Treat CTC trial. Eur J Cancer. 2016; 63: 97104. doi: 10.1016/j.ejca.2016.04.024. 
38. Alix-Panabieres C, Pantel K. Challenges in circulating tumour cell research. Nat Rev Cancer. 2014; 14: 623-31. doi: $10.1038 / \mathrm{nrc} 3820$.

39. Fischer JC, Niederacher D, Topp SA, Honisch E, Schumacher S, Schmitz N, Zacarias Fohrding L, Vay C, Hoffmann I, Kasprowicz NS, Hepp PG, Mohrmann S, Nitz U, et al. Diagnostic leukapheresis enables reliable detection of circulating tumor cells of nonmetastatic cancer patients. Proc Natl Acad Sci U S A. 2013; 110: 16580-5. doi: 10.1073/pnas.1313594110.

40. Ma M, Zhu H, Zhang C, Sun X, Gao X, Chen G. "Liquid biopsy"-ctDNA detection with great potential and challenges. Ann Transl Med. 2015; 3: 235. doi: 10.3978/j. issn.2305-5839.2015.09.29.

41. Kato K, Uchida J, Kukita Y, Kumagai T, Nishino K, Inoue T, Kimura M, Oba S, Imamura F. Numerical indices based on circulating tumor DNA for the evaluation of therapeutic response and disease progression in lung cancer patients. Sci Rep. 2016; 6: 29093. doi: 10.1038/srep29093.

42. Bettegowda C, Sausen M, Leary RJ, Kinde I, Wang Y, Agrawal N, Bartlett BR, Wang H, Luber B, Alani RM, Antonarakis ES, Azad NS, Bardelli A, et al. Detection of circulating tumor DNA in early- and late-stage human malignancies. Sci Transl Med. 2014; 6: 224ra24. doi: 10.1126/scitranslmed.3007094.

43. Newman AM, Bratman SV, To J, Wynne JF, Eclov NC, Modlin LA, Liu CL, Neal JW, Wakelee HA, Merritt RE, Shrager JB, Loo BW, Jr., Alizadeh AA, et al. An ultrasensitive method for quantitating circulating tumor DNA with broad patient coverage. Nat Med. 2014; 20: 54854. doi: 10.1038/nm.3519.

44. Dawson SJ, Rosenfeld N, Caldas C. Circulating tumor DNA to monitor metastatic breast cancer. N Engl J Med. 2013; 369: 93-4. doi: 10.1056/NEJMc1306040.

45. Dawson SJ, Tsui DW, Murtaza M, Biggs H, Rueda OM, Chin SF, Dunning MJ, Gale D, Forshew T, MahlerAraujo B, Rajan S, Humphray S, Becq J, et al. Analysis of circulating tumor DNA to monitor metastatic breast cancer. N Engl J Med. 2013; 368: 1199-209. doi: 10.1056/ NEJMoa1213261.

46. Baccelli I, Schneeweiss A, Riethdorf S, Stenzinger A, Schillert A, Vogel V, Klein C, Saini M, Bauerle T, Wallwiener M, Holland-Letz T, Hofner T, Sprick M, et al. Identification of a population of blood circulating tumor cells from breast cancer patients that initiates metastasis in a xenograft assay. Nat Biotechnol. 2013; 31: 539-44. doi: 10.1038/nbt.2576.

47. Cristofanilli M, Budd GT, Ellis MJ, Stopeck A, Matera J, Miller MC, Reuben JM, Doyle GV, Allard WJ, Terstappen LW, Hayes DF. Circulating tumor cells, disease progression, and survival in metastatic breast cancer. N Engl J Med. 2004; 351: 781-91. doi: 10.1056/NEJMoa040766.

48. Hayes DF, Cristofanilli M, Budd GT, Ellis MJ, Stopeck A, Miller MC, Matera J, Allard WJ, Doyle GV, Terstappen LW. Circulating tumor cells at each follow-up time point during therapy of metastatic breast cancer patients predict progression-free and overall survival. Clin Cancer Res. 2006; 12: 4218-24. doi: 10.1158/1078-0432.CCR-05-2821.

49. de Bono JS, Scher HI, Montgomery RB, Parker C, Miller MC, Tissing H, Doyle GV, Terstappen LW, Pienta KJ, Raghavan D. Circulating tumor cells predict survival benefit from treatment in metastatic castration-resistant prostate cancer. Clin Cancer Res. 2008; 14: 6302-9. doi: 10.1158/1078-0432.CCR-08-0872.

50. Yap TA, Lorente D, Omlin A, Olmos D, de Bono JS. Circulating tumor cells: a multifunctional biomarker. Clin Cancer Res. 2014; 20: 2553-68. doi: 10.1158/1078-0432. CCR-13-2664.

51. Moreno JG, O'Hara SM, Gross S, Doyle G, Fritsche H, Gomella LG, Terstappen LW. Changes in circulating carcinoma cells in patients with metastatic prostate cancer correlate with disease status. Urology. 2001; 58: 386-92.

52. Allard WJ, Matera J, Miller MC, Repollet M, Connelly MC, Rao C, Tibbe AG, Uhr JW, Terstappen LW. Tumor cells circulate in the peripheral blood of all major carcinomas but not in healthy subjects or patients with nonmalignant diseases. Clin Cancer Res. 2004; 10: 6897-904. doi: 10.1158/1078-0432.CCR-04-0378.

53. Budd GT, Cristofanilli M, Ellis MJ, Stopeck A, Borden E, Miller MC, Matera J, Repollet M, Doyle GV, Terstappen LW, Hayes DF. Circulating tumor cells versus imaging-predicting overall survival in metastatic breast cancer. Clin Cancer Res. 2006; 12: 6403-9. doi: 10.1158/1078-0432. CCR-05-1769.

54. Pantel K, Alix-Panabieres C. Circulating tumour cells in cancer patients: challenges and perspectives. Trends Mol Med. 2010; 16: 398-406. doi: S1471-4914(10)00096-1 [pii]10.1016/j.molmed.2010.07.001.

55. Cristofanilli M. Circulating tumor cells, disease progression, and survival in metastatic breast cancer. Semin Oncol. 2006; 33: S9-14. doi: 10.1053/j.seminoncol.2006.03.016.

56. Coumans FA, Ligthart ST, Uhr JW, Terstappen LW. Challenges in the enumeration and phenotyping of CTC. Clin Cancer Res. 2012; 18: 5711-8. doi: 10.1158/10780432.CCR-12-1585.

57. Coumans FA, Siesling S, Terstappen LW. Detection of cancer before distant metastasis. BMC Cancer. 2013; 13: 283. doi: 10.1186/1471-2407-13-283.

58. Pantel K, Alix-Panabieres C. The potential of circulating tumor cells as a liquid biopsy to guide therapy in prostate cancer. Cancer Discov. 2012; 2: 974-5. doi: 10.1158/21598290.CD-12-0432.

59. Jacob K, Sollier C, Jabado N. Circulating tumor cells: detection, molecular profiling and future prospects. Expert Rev Proteomics. 2007; 4: 741-56. doi: 10.1586/14789450.4.6.741.

60. Tewes M, Aktas B, Welt A, Mueller S, Hauch S, Kimmig $\mathrm{R}$, Kasimir-Bauer S. Molecular profiling and predictive value of circulating tumor cells in patients with metastatic 
breast cancer: an option for monitoring response to breast cancer related therapies. Breast Cancer Res Treat. 2009; 115: 581-90. doi: 10.1007/s10549-008-0143-x.

61. Husemann Y, Geigl JB, Schubert F, Musiani P, Meyer M, Burghart E, Forni G, Eils R, Fehm T, Riethmuller G, Klein CA. Systemic spread is an early step in breast cancer. Cancer Cell. 2008; 13: 58-68.

62. Klein CA, Blankenstein TJ, Schmidt-Kittler O, Petronio M, Polzer B, Stoecklein NH, Riethmuller G. Genetic heterogeneity of single disseminated tumour cells in minimal residual cancer. Lancet. 2002; 360: 683-9.

63. Klein CA, Seidl S, Petat-Dutter K, Offner S, Geigl JB, Schmidt-Kittler O, Wendler N, Passlick B, Huber RM, Schlimok G, Baeuerle PA, Riethmuller G. Combined transcriptome and genome analysis of single micrometastatic cells. Nat Biotechnol. 2002; 20: 387-92.

64. Polzer B, Medoro G, Pasch S, Fontana F, Zorzino L, Pestka A, Andergassen U, Meier-Stiegen F, Czyz ZT, Alberter B, Treitschke S, Schamberger T, Sergio M, et al. Molecular profiling of single circulating tumor cells with diagnostic intention. EMBO Mol Med. 2014; 6: 1371-86. doi: 10.15252/emmm.201404033.

65. Schardt JA, Meyer M, Hartmann CH, Schubert F, SchmidtKittler O, Fuhrmann C, Polzer B, Petronio M, Eils R, Klein CA. Genomic analysis of single cytokeratin-positive cells from bone marrow reveals early mutational events in breast cancer. Cancer Cell. 2005; 8: 227-39.

66. Schmidt-Kittler O, Ragg T, Daskalakis A, Granzow M, Ahr A, Blankenstein TJ, Kaufmann M, Diebold J, Arnholdt H, Muller P, Bischoff J, Harich D, Schlimok G, et al. From latent disseminated cells to overt metastasis: genetic analysis of systemic breast cancer progression. Proc Natl Acad Sci U S A. 2003; 100: 7737-42.

67. Stoecklein NH, Hosch SB, Bezler M, Stern F, Hartmann $\mathrm{CH}$, Vay C, Siegmund A, Scheunemann P, Schurr P, Knoefel WT, Verde PE, Reichelt U, Erbersdobler A, et al. Direct genetic analysis of single disseminated cancer cells for prediction of outcome and therapy selection in esophageal cancer. Cancer Cell. 2008; 13: 441-53. doi: S1535-6108(08)00124-4 [pii]10.1016/j.ccr.2008.04.005.

68. Stoecklein NH, Klein CA. Genetic disparity between primary tumours, disseminated tumour cells, and manifest metastasis. Int J Cancer. 2010; 126: 589-98. doi: 10.1002/ ijc.24916.

69. Klein CA. Parallel progression of primary tumours and metastases. Nat Rev Cancer. 2009; 9: 302-12. doi: 10.1038/ nrc2627.

70. Alix-Panabieres C, Riethdorf S, Pantel K. Circulating tumor cells and bone marrow micrometastasis. Clin Cancer Res. 2008; 14: 5013-21. doi: 14/16/5013 [pii]10.1158/10780432.CCR-07-5125.

71. Kang Y, Pantel K. Tumor cell dissemination: emerging biological insights from animal models and cancer patients. Cancer Cell. 2013; 23: 573-81. doi: 10.1016/j. ccr.2013.04.017.

72. Muller V, Riethdorf S, Rack B, Janni W, Fasching PA, Solomayer E, Aktas B, Kasimir-Bauer S, Pantel K, Fehm T, on behalf of the Dsg. Prognostic impact of circulating tumor cells assessed with the CellSearch System and AdnaTest Breast in metastatic breast cancer patients: the DETECT study. Breast Cancer Res. 2012; 14: R118. doi: 10.1186/ bcr3243.

73. Muller V, Stahmann N, Riethdorf S, Rau T, Zabel T, Goetz A, Janicke F, Pantel K. Circulating tumor cells in breast cancer: correlation to bone marrow micrometastases, heterogeneous response to systemic therapy and low proliferative activity. Clin Cancer Res. 2005; 11: 3678-85.

74. Pantel K, Brakenhoff RH, Brandt B. Detection, clinical relevance and specific biological properties of disseminating tumour cells. Nat Rev Cancer. 2008; 8: 329-40.

75. Pantel K, Woelfle U. Detection and molecular characterisation of disseminated tumour cells: implications for anti-cancer therapy. Biochim Biophys Acta. 2005; 1756: 53-64.

76. Rack B, Schindlbeck C, Juckstock J, Andergassen U, Hepp P, Zwingers T, Friedl TW, Lorenz R, Tesch H, Fasching PA, Fehm T, Schneeweiss A, Lichtenegger W, et al. Circulating tumor cells predict survival in early average-tohigh risk breast cancer patients. J Natl Cancer Inst. 2014; 106. doi: 10.1093/jnci/dju066.

77. Schulze K, Gasch C, Staufer K, Nashan B, Lohse AW, Pantel K, Riethdorf S, Wege H. Presence of EpCAMpositive circulating tumor cells as biomarker for systemic disease strongly correlates to survival in patients with hepatocellular carcinoma. Int J Cancer. 2013; 133: 2165 71. doi: 10.1002/ijc.28230.

78. Wallwiener M, Hartkopf AD, Baccelli I, Riethdorf S, Schott S, Pantel K, Marme F, Sohn C, Trumpp A, Rack B, Aktas B, Solomayer EF, Muller V, et al. The prognostic impact of circulating tumor cells in subtypes of metastatic breast cancer. Breast Cancer Res Treat. 2013; 137: 503-10. doi: 10.1007/s10549-012-2382-0.

79. Zhang L, Riethdorf S, Wu G, Wang T, Yang K, Peng G, Liu J, Pantel K. Meta-analysis of the prognostic value of circulating tumor cells in breast cancer. Clin Cancer Res. 2012; 18: 5701-10. doi: 10.1158/1078-0432.CCR-12-1587.

80. Onstenk W, Gratama JW, Foekens JA, Sleijfer S. Towards a personalized breast cancer treatment approach guided by circulating tumor cell (CTC) characteristics. Cancer Treat Rev. 2013; 39: 691-700. doi: 10.1016/j.ctrv.2013.04.001.

81. Goss PE, Chambers AF. Does tumour dormancy offer a therapeutic target? Nat Rev Cancer. 2010; 10: 871-7. doi: $10.1038 / \mathrm{nrc} 2933$.

82. Janni W, Rack B, Schindlbeck C, Strobl B, Rjosk D, Braun S, Sommer H, Pantel K, Gerber B, Friese K. The persistence of isolated tumor cells in bone marrow from patients with 
breast carcinoma predicts an increased risk for recurrence. Cancer. 2005; 103: 884-91.

83. Pantel K, Alix-Panabieres C, Riethdorf S. Cancer micrometastases. Nat Rev Clin Oncol. 2009; 6: 339-51. doi: nrclinonc.2009.44 [pii]10.1038/nrclinonc.2009.44.

84. Riethdorf S, Wikman H, Pantel K. Review: Biological relevance of disseminated tumor cells in cancer patients. Int J Cancer. 2008; 123: 1991-2006. doi: 10.1002/ijc.23825.

85. Klein CA, Stoecklein NH. Lessons from an aggressive cancer: evolutionary dynamics in esophageal carcinoma. Cancer Res. 2009; 69: 5285-8. doi: 0008-5472.CAN-084586 [pii]10.1158/0008-5472.CAN-08-4586.

86. Klein CA. The systemic progression of human cancer: a focus on the individual disseminated cancer cell--the unit of selection. Adv Cancer Res. 2003; 89: 35-67.

87. Riethdorf S, Pantel K. Disseminated tumor cells in bone marrow and circulating tumor cells in blood of breast cancer patients: current state of detection and characterization. Pathobiology. 2008; 75: 140-8. doi: 000123852 [pii]10.1159/000123852.

88. Hosch S, Kraus J, Scheunemann P, Izbicki JR, Schneider C, Schumacher U, Witter K, Speicher MR, Pantel K. Malignant potential and cytogenetic characteristics of occult disseminated tumor cells in esophageal cancer. Cancer Res. 2000; 60: 6836-40. doi:

89. Hodgkinson CL, Morrow CJ, Li Y, Metcalf RL, Rothwell DG, Trapani F, Polanski R, Burt DJ, Simpson KL, Morris K, Pepper SD, Nonaka D, Greystoke A, et al. Tumorigenicity and genetic profiling of circulating tumor cells in small-cell lung cancer. Nat Med. 2014; 20: 897-903. doi: $10.1038 / \mathrm{nm} .3600$.

90. Aceto N, Bardia A, Miyamoto DT, Donaldson MC, Wittner BS, Spencer JA, Yu M, Pely A, Engstrom A, Zhu H, Brannigan BW, Kapur R, Stott SL, et al. Circulating tumor cell clusters are oligoclonal precursors of breast cancer metastasis. Cell. 2014; 158: 1110-22. doi: 10.1016/j. cell.2014.07.013.

91. Morrow CJ, Trapani F, Metcalf RL, Bertolini G, Hodgkinson CL, Khandelwal G, Kelly P, Galvin M, Carter L, Simpson KL, Williamson S, Wirth C, Simms N, et al. Tumourigenic non-small-cell lung cancer mesenchymal circulating tumour cells: a clinical case study. Ann Oncol. 2016; 27: 1155-60. doi: 10.1093/annonc/mdw122.

92. Girotti MR, Gremel G, Lee R, Galvani E, Rothwell D, Viros A, Mandal AK, Lim KH, Saturno G, Furney SJ, Baenke F, Pedersen M, Rogan J, et al. Application of Sequencing, Liquid Biopsies, and Patient-Derived Xenografts for Personalized Medicine in Melanoma. Cancer Discov. 2016; 6: 286-99. doi: 10.1158/2159-8290.CD-15-1336.

93. Fidler IJ. Tumor heterogeneity and the biology of cancer invasion and metastasis. Cancer Res. 1978; 38: 2651-60.

94. Campbell LL, Polyak K. Breast tumor heterogeneity: cancer stem cells or clonal evolution? Cell Cycle. 2007; 6: 2332-8.

95. Mani SA, Guo W, Liao MJ, Eaton EN, Ayyanan A, Zhou
AY, Brooks M, Reinhard F, Zhang CC, Shipitsin M, Campbell LL, Polyak K, Brisken C, et al. The epithelialmesenchymal transition generates cells with properties of stem cells. Cell. 2008; 133: 704-15. doi: S00928674(08)00444-3 [pii]10.1016/j.cell.2008.03.027.

96. Polyak K, Weinberg RA. Transitions between epithelial and mesenchymal states: acquisition of malignant and stem cell traits. Nat Rev Cancer. 2009; 9: 265-73. doi: 10.1038/ nrc2620.

97. Shipitsin M, Campbell LL, Argani P, Weremowicz S, Bloushtain-Qimron N, Yao J, Nikolskaya T, Serebryiskaya T, Beroukhim R, Hu M, Halushka MK, Sukumar S, Parker LM, et al. Molecular definition of breast tumor heterogeneity. Cancer Cell. 2007; 11: 259-73.

98. Brouwer A, De Laere B, Peeters D, Peeters M, Salgado R, Dirix L, Van Laere S. Evaluation and consequences of heterogeneity in the circulating tumor cell compartment. Oncotarget. 2016; 7:48625-48643. doi: 10.18632/ oncotarget. 8015 .

99. Tam WL, Weinberg RA. The epigenetics of epithelialmesenchymal plasticity in cancer. Nat Med. 2013; 19: 1438-49. doi: 10.1038/nm.3336.

100. Lujambio A, Esteller M. How epigenetics can explain human metastasis: a new role for microRNAs. Cell Cycle. 2009; 8: 377-82.

101. Nierodzik ML, Karpatkin S. Thrombin induces tumor growth, metastasis, and angiogenesis: Evidence for a thrombin-regulated dormant tumor phenotype. Cancer Cell. 2006; 10: 355-62. doi: 10.1016/j.ccr.2006.10.002.

102. Barkan D, Kleinman H, Simmons JL, Asmussen H, Kamaraju AK, Hoenorhoff MJ, Liu ZY, Costes SV, Cho EH, Lockett S, Khanna C, Chambers AF, Green JE. Inhibition of metastatic outgrowth from single dormant tumor cells by targeting the cytoskeleton. Cancer Res. 2008; 68: 6241-50. doi: 10.1158/0008-5472.CAN-07-6849.

103. Quesnel B. Dormant tumor cells as a therapeutic target? Cancer Lett. 2008; 267: 10-7. doi: 10.1016/j. canlet.2008.02.055.

104. Sosa MS, Bragado P, Aguirre-Ghiso JA. Mechanisms of disseminated cancer cell dormancy: an awakening field. Nat Rev Cancer. 2014; 14: 611-22. doi: 10.1038/nrc3793.

105. Ghajar CM. Metastasis prevention by targeting the dormant niche. Nat Rev Cancer. 2015; 15: 238-47. doi: 10.1038/ nrc3910.

106. Ghajar CM, Peinado H, Mori H, Matei IR, Evason KJ, Brazier H, Almeida D, Koller A, Hajjar KA, Stainier DY, Chen EI, Lyden D, Bissell MJ. The perivascular niche regulates breast tumour dormancy. Nat Cell Biol. 2013; 15: 807-17. doi: 10.1038/ncb2767.

107. Thiery JP, Acloque H, Huang RY, Nieto MA. Epithelialmesenchymal transitions in development and disease. Cell. 2009; 139: 871-90. doi: 10.1016/j.cell.2009.11.007.

108. Thiery JP, Lim CT. Tumor dissemination: an EMT affair. Cancer Cell. 2013; 23: 272-3. doi: 10.1016/j. 
ccr.2013.03.004.

109. Chaffer CL, Weinberg RA. A perspective on cancer cell metastasis. Science. 2011; 331: 1559-64. doi: 10.1126/ science. 1203543 .

110. Hanahan D, Weinberg RA. Hallmarks of cancer: the next generation. Cell. 2011; 144: 646-74. doi: S00928674(11)00127-9 [pii]10.1016/j.cell.2011.02.013.

111. Braun S, Hepp F, Sommer HL, Pantel K. Tumor-antigen heterogeneity of disseminated breast cancer cells: implications for immunotherapy of minimal residual disease. Int J Cancer. 1999; 84: 1-5. doi:

112. Thurm H, Ebel S, Kentenich C, Hemsen A, Riethdorf S, Coith C, Wallwiener D, Braun S, Oberhoff C, Janicke F, Pantel K. Rare expression of epithelial cell adhesion molecule on residual micrometastatic breast cancer cells after adjuvant chemotherapy. Clin Cancer Res. 2003; 9: 2598-604.

113. Weigelt B, Glas AM, Wessels LF, Witteveen AT, Peterse JL, van't Veer LJ. Gene expression profiles of primary breast tumors maintained in distant metastases. Proc Natl Acad Sci U S A. 2003; 100: 15901-5. doi: 10.1073/ pnas.2634067100.

114. Weigelt B, Hu Z, He X, Livasy C, Carey LA, Ewend MG, Glas AM, Perou CM, Van't Veer LJ. Molecular portraits and 70-gene prognosis signature are preserved throughout the metastatic process of breast cancer. Cancer Res. 2005; 65: 9155-8. doi: 10.1158/0008-5472.CAN-05-2553.

115. Hao X, Sun B, Hu L, Lahdesmaki H, Dunmire V, Feng Y, Zhang SW, Wang H, Wu C, Wang H, Fuller GN, Symmans WF, Shmulevich I, et al. Differential gene and protein expression in primary breast malignancies and their lymph node metastases as revealed by combined cDNA microarray and tissue microarray analysis. Cancer. 2004; 100: 1110-22. doi: 10.1002/cncr.20095.

116. Bukholm IK, Nesland JM, Borresen-Dale AL. Reexpression of E-cadherin, alpha-catenin and beta-catenin, but not of gamma-catenin, in metastatic tissue from breast cancer patients [seecomments]. J Pathol. 2000; 190: 15-9. doi: 10.1002/(SICI)1096-9896(200001)190:1<15::AIDPATH489>3.0.CO;2-L.

117. Weigelt B, Peterse JL, van 't Veer LJ. Breast cancer metastasis: markers and models. Nat Rev Cancer. 2005; 5: 591-602. doi: 10.1038/nrc1670.

118. Nacht M, Ferguson AT, Zhang W, Petroziello JM, Cook BP, Gao YH, Maguire S, Riley D, Coppola G, Landes GM, Madden SL, Sukumar S. Combining serial analysis of gene expression and array technologies to identify genes differentially expressed in breast cancer. Cancer Res. 1999; 59: 5464-70. doi:

119. Iwatsuki M, Toyoshima K, Watanabe M, Hayashi N, Ishimoto T, Eto K, Iwagami S, Baba Y, Yoshida N, Hayashi A, Ohta Y, Baba H. Frequency of HER2 expression of circulating tumour cells in patients with metastatic or recurrent gastrointestinal cancer. Br J Cancer. 2013; 109:
2829-32. doi: 10.1038/bjc.2013.680.

120. Solomayer EF, Becker S, Pergola-Becker G, Bachmann R, Kramer B, Vogel U, Neubauer H, Wallwiener D, Huober J, Fehm TN. Comparison of HER2 status between primary tumor and disseminated tumor cells in primary breast cancer patients. Breast Cancer Res Treat. 2006; 98: 179-84. doi: 10.1007/s10549-005-9147-y.

121. Maheswaran S, Sequist LV, Nagrath S, Ulkus L, Brannigan B, Collura CV, Inserra E, Diederichs S, Iafrate AJ, Bell DW, Digumarthy S, Muzikansky A, Irimia D, et al. Detection of mutations in EGFR in circulating lung-cancer cells. N Engl J Med. 2008; 359: 366-77. doi: 10.1056/ NEJMoa0800668.

122. Polzer B, Klein CA. Metastasis awakening: the challenges of targeting minimal residual cancer. Nat Med. 2013; 19: 274-5. doi: 10.1038/nm.3121.

123. Ramaswamy S, Ross KN, Lander ES, Golub TR. A molecular signature of metastasis in primary solid tumors. Nat Genet. 2003; 33: 49-54. doi: 10.1038/ng1060.

124. Barradas AM, Terstappen LW. Towards the Biological Understanding of CTC: Capture Technologies, Definitions and Potential to Create Metastasis. Cancers (Basel). 2013; 5: 1619-42. doi: 10.3390/cancers5041619.

125. Cohen SJ, Punt CJ, Iannotti N, Saidman BH, Sabbath KD, Gabrail NY, Picus J, Morse M, Mitchell E, Miller MC, Doyle GV, Tissing H, Terstappen LW, et al. Relationship of circulating tumor cells to tumor response, progressionfree survival, and overall survival in patients with metastatic colorectal cancer. J Clin Oncol. 2008; 26: 3213-21. doi: 10.1200/JCO.2007.15.8923.

126. Cohen SJ, Punt CJ, Iannotti N, Saidman BH, Sabbath KD, Gabrail NY, Picus J, Morse MA, Mitchell E, Miller MC, Doyle GV, Tissing H, Terstappen LW, et al. Prognostic significance of circulating tumor cells in patients with metastatic colorectal cancer. Ann Oncol. 2009; 20: 1223-9. doi: 10.1093/annonc/mdn786.

127. Hiltermann TJ, Pore MM, van den Berg A, Timens W, Boezen HM, Liesker JJ, Schouwink JH, Wijnands WJ, Kerner GS, Kruyt FA, Tissing H, Tibbe AG, Terstappen LW, et al. Circulating tumor cells in small-cell lung cancer: a predictive and prognostic factor. Ann Oncol. 2012; 23: 2937-42. doi: 10.1093/annonc/mds138.

128. Powell AA, Talasaz AH, Zhang H, Coram MA, Reddy A, Deng G, Telli ML, Advani RH, Carlson RW, Mollick JA, Sheth S, Kurian AW, Ford JM, et al. Single cell profiling of circulating tumor cells: transcriptional heterogeneity and diversity from breast cancer cell lines. PLoS One. 2012; 7: e33788. doi: 10.1371/journal.pone.0033788.

129. Riethdorf S, Fritsche H, Muller V, Rau T, Schindlbeck C, Rack B, Janni W, Coith C, Beck K, Janicke F, Jackson S, Gornet T, Cristofanilli M, et al. Detection of circulating tumor cells in peripheral blood of patients with metastatic breast cancer: a validation study of the CellSearch system. Clin Cancer Res. 2007; 13: 920-8. 
130. Zoller M. CD44: can a cancer-initiating cell profit from an abundantly expressed molecule? Nat Rev Cancer. 2011; 11: 254-67. doi: $\operatorname{nrc3023}$ [pii]10.1038/nrc3023.

131. Al-Hajj M, Wicha MS, Benito-Hernandez A, Morrison SJ, Clarke MF. Prospective identification of tumorigenic breast cancer cells. Proc Natl Acad Sci U S A. 2003; 100: 3983-8.

132. Hofmann M, Rudy W, Zoller M, Tolg C, Ponta H, Herrlich $\mathrm{P}$, Gunthert U. CD44 splice variants confer metastatic behavior in rats: homologous sequences are expressed in human tumor cell lines. Cancer Res. 1991; 51: 5292-7. doi:

133. Hiraga T, Ito S, Nakamura H. Cancer stem-like cell marker CD44 promotes bone metastases by enhancing tumorigenicity, cell motility, and hyaluronan production. Cancer Res. 2013; 73: 4112-22. doi: 10.1158/0008-5472. CAN-12-3801.

134. Nagahara M, Mimori K, Kataoka A, Ishii H, Tanaka F, Nakagawa T, Sato T, Ono S, Sugihara K, Mori M. Correlated expression of CD47 and SIRPA in bone marrow and in peripheral blood predicts recurrence in breast cancer patients. Clin Cancer Res. 2010; 16: 4625-35. doi: 10.1158/1078-0432.CCR-10-0349.

135. Trusolino L, Bertotti A, Comoglio PM. MET signalling: principles and functions in development, organ regeneration and cancer. Nat Rev Mol Cell Biol. 2010; 11: 834-48. doi: 10.1038/nrm3012.

136. Gires O, Klein CA, Baeuerle PA. On the abundance of EpCAM on cancer stem cells. Nat Rev Cancer. 2009; 9: 143; author reply doi: nrc2499-c1 [pii]10.1038/nrc2499-c1.

137. Visvader JE, Lindeman GJ. Cancer stem cells in solid tumours: accumulating evidence and unresolved questions. Nat Rev Cancer. 2008; 8: 755-68. doi:

138. Gires O. Lessons from common markers of tumor-initiating cells in solid cancers. Cell Mol Life Sci. 2011. doi: 10.1007/ s00018-011-0772-9.

139. Munz M, Baeuerle PA, Gires O. The emerging role of EpCAM in cancer and stem cell signaling. Cancer Res. 2009; 69: 5627-9. doi: 0008-5472.CAN-09-0654 [pii]10.1158/0008-5472.CAN-09-0654.

140. Du L, Wang H, He L, Zhang J, Ni B, Wang X, Jin H, Cahuzac N, Mehrpour M, Lu Y, Chen Q. CD44 is of functional importance for colorectal cancer stem cells. Clin Cancer Res. 2008; 14: 6751-60. doi: 10.1158/1078-0432. CCR-08-1034.

141. Sieuwerts AM, Kraan J, Bolt J, van der Spoel P, Elstrodt F, Schutte M, Martens JW, Gratama JW, Sleijfer S, Foekens JA. Anti-epithelial cell adhesion molecule antibodies and the detection of circulating normal-like breast tumor cells. J Natl Cancer Inst. 2009; 101: 61-6. doi: 10.1093/jnci/djn419.

142. Went P, Vasei M, Bubendorf L, Terracciano L, Tornillo L, Riede U, Kononen J, Simon R, Sauter G, Baeuerle PA. Frequent high-level expression of the immunotherapeutic target Ep-CAM in colon, stomach, prostate and lung cancers. Br J Cancer. 2006; 94: 128-35.

143. Went PT, Lugli A, Meier S, Bundi M, Mirlacher M, Sauter
G, Dirnhofer S. Frequent EpCam protein expression in human carcinomas. Hum Pathol. 2004; 35: 122-8.

144. Brabletz T, Jung A, Spaderna S, Hlubek F, Kirchner T. Opinion: migrating cancer stem cells - an integrated concept of malignant tumour progression. Nat Rev Cancer. 2005; 5: 744-9. doi: nrc1694 [pii]10.1038/nrc1694.

145. Liu WF, Nelson CM, Pirone DM, Chen CS. E-cadherin engagement stimulates proliferation via Rac1. J Cell Biol. 2006; 173: 431-41. doi: 10.1083/jcb.200510087.

146. van Roy F, Berx G. The cell-cell adhesion molecule E-cadherin. Cell Mol Life Sci. 2008; 65: 3756-88. doi: 10.1007/s00018-008-8281-1.

147. Cavallaro U, Schaffhauser B, Christofori G. Cadherins and the tumour progression: is it all in a switch? Cancer Lett. 2002; 176: 123-8.

148. Kolijn K, Verhoef EI, van Leenders GJ. Morphological and immunohistochemical identification of epithelialto-mesenchymal transition in clinical prostate cancer. Oncotarget. 2015; 6: 24488-98. doi:10.18632/ oncotarget. 4177.

149. Canel M, Serrels A, Frame MC, Brunton VG. E-cadherinintegrin crosstalk in cancer invasion and metastasis. J Cell Sci. 2013; 126: 393-401. doi: 10.1242/jcs.100115.

150. de Wit S, van Dalum G, Lenferink AT, Tibbe AG, Hiltermann TJ, Groen HJ, van Rijn CJ, Terstappen LW. The detection of $\operatorname{EpCAM}(+)$ and $\operatorname{EpCAM}(-)$ circulating tumor cells. Sci Rep. 2015; 5: 12270. doi: 10.1038/srep12270.

151. Rao CG, Chianese D, Doyle GV, Miller MC, Russell T, Sanders RA, Jr., Terstappen LW. Expression of epithelial cell adhesion molecule in carcinoma cells present in blood and primary and metastatic tumors. Int J Oncol. 2005; 27 : 49-57.

152. Mikolajczyk SD, Millar LS, Tsinberg P, Coutts SM, Zomorrodi M, Pham T, Bischoff FZ, Pircher TJ. Detection of EpCAM-Negative and Cytokeratin-Negative Circulating Tumor Cells in Peripheral Blood. J Oncol. 2011; 2011: 252361. doi: 10.1155/2011/252361.

153. Konigsberg R, Obermayr E, Bises G, Pfeiler G, Gneist M, Wrba F, de Santis M, Zeillinger R, Hudec M, Dittrich C. Detection of EpCAM positive and negative circulating tumor cells in metastatic breast cancer patients. Acta Oncol. 2012; 50: 700-10. doi: 10.3109/0284186X.2010.549151.

154. Schneck H, Gierke B, Uppenkamp F, Behrens B, Niederacher D, Stoecklein NH, Templin MF, Pawlak M, Fehm T, Neubauer H, Disseminated Cancer Cell Network D. EpCAM-Independent Enrichment of Circulating Tumor Cells in Metastatic Breast Cancer. PLoS One. 2015; 10: e0144535. doi: 10.1371/journal.pone.0144535.

155. Kim MJ, Choi NY, Lee EK, Kang MS. Identification of novel markers that outperform EpCAM in quantifying circulating tumor cells. Cell Oncol (Dordr). 2014; 37: 235 43. doi: 10.1007/s13402-014-0178-4.

156. Chaves-Perez A, Mack B, Maetzel D, Kremling H, Eggert C, Harreus U, Gires O. EpCAM regulates cell cycle 
progression via control of cyclin D1 expression. Oncogene. 2013; 32: 641-50. doi: 10.1038/onc.2012.75.

157. Imrich S, Hachmeister M, Gires O. EpCAM and its potential role in tumor-initiating cells. Cell Adh Migr. 2012; 6: 30-8. doi: 18953 [pii]10.4161/cam.18953.

158. Maetzel D, Denzel S, Mack B, Canis M, Went P, Benk M, Kieu C, Papior P, Baeuerle PA, Munz M, Gires O. Nuclear signalling by tumour-associated antigen EpCAM. Nat Cell Biol. 2009; 11: 162-71. doi:

159. Maaser K, Borlak J. A genome-wide expression analysis identifies a network of EpCAM-induced cell cycle regulators. Br J Cancer. 2008; 99: 1635-43. doi:

160. Tsaktanis T, Kremling H, Pavsic M, von Stackelberg R, Mack B, Fukumori A, Steiner H, Vielmuth F, Spindler V, Huang Z, Jakubowski J, Stoecklein NH, Luxenburger E, et al. Cleavage and Cell Adhesion Properties of Human Epithelial Cell Adhesion Molecule hEpCAM. J Biol Chem. 2015. doi: 10.1074/jbc.M115.662700.

161. Gosens MJ, van Kempen LC, van de Velde CJ, van Krieken $\mathrm{JH}$, Nagtegaal ID. Loss of membranous Ep-CAM in budding colorectal carcinoma cells. Mod Pathol. 2007; 20: 221-32. doi: 10.1038/modpathol.3800733.

162. Biddle A, Liang X, Gammon L, Fazil B, Harper LJ, Emich H, Costea DE, Mackenzie IC. Cancer stem cells in squamous cell carcinoma switch between two distinct phenotypes that are preferentially migratory or proliferative. Cancer Res. 2011; 71: 5317-26. doi: 0008-5472.CAN-111059 [pii]10.1158/0008-5472.CAN-11-1059.

163. Maghzal N, Vogt E, Reintsch W, Fraser JS, Fagotto F. The tumor-associated EpCAM regulates morphogenetic movements through intracellular signaling. J Cell Biol. 2010; 191: 645-59. doi: jcb.201004074 [pii]10.1083/ jcb.201004074.

164. Maghzal N, Kayali HA, Rohani N, Kajava AV, Fagotto F. EpCAM controls actomyosin contractility and cell adhesion by direct inhibition of PKC. Dev Cell. 2013; 27: 263-77. doi: 10.1016/j.devcel.2013.10.003.

165. Osta WA, Chen Y, Mikhitarian K, Mitas M, Salem M, Hannun YA, Cole DJ, Gillanders WE. EpCAM is overexpressed in breast cancer and is a potential target for breast cancer gene therapy. Cancer Res. 2004; 64: 5818-24.

166. Sankpal NV, Willman MW, Fleming TP, Mayfield JD, Gillanders WE. Transcriptional Repression of Epithelial Cell Adhesion Molecule Contributes to p53 Control of Breast Cancer Invasion. Cancer Res. 2009.

167. Munz M, Kieu C, Mack B, Schmitt B, Zeidler R, Gires O. The carcinoma-associated antigen EpCAM upregulates c-myc and induces cell proliferation. Oncogene. 2004; 23: 5748-58.

168. Baeuerle PA, Gires O. EpCAM (CD326) finding its role in cancer. Br J Cancer. 2007; 96: 417-23.

169. Carpenter G, Red Brewer M. EpCAM: Another Surface-toNucleus Missile. Cancer Cell. 2009; 15: 165-6. doi: S15356108(09)00038-5 [pii]10.1016/j.ccr.2009.02.005.
170. Pickersgill H. Journey into the center of the cell. Science. 2009; 323.

171. Lu TY, Lu RM, Liao MY, Yu J, Chung CH, Kao CF, $\mathrm{Wu} \mathrm{HC}$. Epithelial cell adhesion molecule regulation is associated with the maintenance of the undifferentiated phenotype of human embryonic stem cells. J Biol Chem. 2010; 285: 8719-32. doi: M109.077081 [pii]10.1074/jbc. M109.077081.

172. Huang HP, Chen PH, Yu CY, Chuang CY, Stone L, Hsiao WC, Li CL, Tsai SC, Chen KY, Chen HF, Ho HN, Kuo HC. Epithelial cell adhesion molecule (EpCAM) complex proteins promote transcription factor-mediated pluripotency reprogramming. J Biol Chem. 2011; 286: 33520-32. doi: M111.256164 [pii]10.1074/jbc.M111.256164.

173. Gonzalez B, Denzel S, Mack B, Conrad M, Gires O. EpCAM Is Involved in Maintenance of the Murine Embryonic Stem Cell Phenotype. Stem Cells. 2009; 27: 1782-91. doi: 10.1002/stem.97.

174. Weller P, Nel I, Hassenkamp P, Gauler T, Schlueter A, Lang S, Dountsop P, Hoffmann AC, Lehnerdt G. Detection of circulating tumor cell subpopulations in patients with head and neck squamous cell carcinoma (HNSCC). PLoS One. 2014; 9: e113706. doi: 10.1371/journal.pone.0113706.

175. Coumans FA, van Dalum G, Beck M, Terstappen LW. Filtration parameters influencing circulating tumor cell enrichment from whole blood. PLoS One. 2013; 8: e61774. doi: 10.1371/journal.pone.0061774.

176. Ge F, Zhang H, Wang DD, Li L, Lin PP. Enhanced detection and comprehensive in situ phenotypic characterization of circulating and disseminated heteroploid epithelial and glioma tumor cells. Oncotarget. 2015; 6: 27049-64. doi: 10.18632/oncotarget.4819.

177. Jiang J, Wang DD, Yang M, Chen D, Pang L, Guo S, Cai J, Wery JP, Li L, Li HQ, Lin PP. Comprehensive characterization of chemotherapeutic efficacy on metastases in the established gastric neuroendocrine cancer patient derived xenograft model. Oncotarget. 2015; 6: 15639-51. doi: 10.18632/oncotarget.3712.

178. Li Y, Zhang X, Ge S, Gao J, Gong J, Lu M, Zhang Q, Cao Y, Wang DD, Lin PP, Shen L. Clinical significance of phenotyping and karyotyping of circulating tumor cells in patients with advanced gastric cancer. Oncotarget. 2014; 5: 6594-602. doi: 10.18632/oncotarget.2175.

179. Menard S, Pupa SM, Campiglio M, Tagliabue E. Biologic and therapeutic role of HER2 in cancer. Oncogene. 2003; 22: 6570-8.

180. Elster N, Collins DM, Toomey S, Crown J, Eustace AJ, Hennessy BT. HER2-family signalling mechanisms, clinical implications and targeting in breast cancer. Breast Cancer Res Treat. 2015; 149: 5-15. doi: 10.1007/s10549014-3250-x.

181. Hudziak RM, Lewis GD, Shalaby MR, Eessalu TE, Aggarwal BB, Ullrich A, Shepard HM. Amplified expression of the HER2/ERBB2 oncogene induces 
resistance to tumor necrosis factor alpha in NIH $3 \mathrm{~T} 3$ cells. Proc Natl Acad Sci U S A. 1988; 85: 5102-6.

182. Hudziak RM, Lewis GD, Winget M, Fendly BM, Shepard HM, Ullrich A. p185HER2 monoclonal antibody has antiproliferative effects in vitro and sensitizes human breast tumor cells to tumor necrosis factor. Mol Cell Biol. 1989; 9: $1165-72$.

183. Sarup JC, Johnson RM, King KL, Fendly BM, Lipari MT, Napier MA, Ullrich A, Shepard HM. Characterization of an anti-p185HER2 monoclonal antibody that stimulates receptor function and inhibits tumor cell growth. Growth Regul. 1991; 1: 72-82.

184. Lee J, Dull TJ, Lax I, Schlessinger J, Ullrich A. HER2 cytoplasmic domain generates normal mitogenic and transforming signals in a chimeric receptor. EMBO J. 1989; 8: 167-73. doi:

185. Hortobagyi GN. Trastuzumab in the treatment of breast cancer. N Engl J Med. 2005; 353: 1734-6. doi: 10.1056/ NEJMe058196.

186. Romond EH, Perez EA, Bryant J, Suman VJ, Geyer CE, Jr., Davidson NE, Tan-Chiu E, Martino S, Paik S, Kaufman PA, Swain SM, Pisansky TM, Fehrenbacher L, et al. Trastuzumab plus adjuvant chemotherapy for operable HER2-positive breast cancer. N Engl J Med. 2005; 353: 1673-84. doi: 10.1056/NEJMoa052122.

187. Shepard HM, Lewis GD, Sarup JC, Fendly BM, Maneval D, Mordenti J, Figari I, Kotts CE, Palladino MA, Jr., Ullrich A, et al. Monoclonal antibody therapy of human cancer: taking the HER2 protooncogene to the clinic. J Clin Immunol. 1991; 11: 117-27.

188. Liu Y, Liu Q, Wang T, Bian L, Zhang S, Hu H, Li S, Hu Z, Wu S, Liu B, Jiang Z. Circulating tumor cells in HER2positive metastatic breast cancer patients: a valuable prognostic and predictive biomarker. BMC Cancer. 2013; 13: 202. doi: 10.1186/1471-2407-13-202.

189. Riethdorf S, Muller V, Zhang L, Rau T, Loibl S, Komor M, Roller M, Huober J, Fehm T, Schrader I, Hilfrich J, Holms F, Tesch H, et al. Detection and HER2 expression of circulating tumor cells: prospective monitoring in breast cancer patients treated in the neoadjuvant GeparQuattro trial. Clin Cancer Res. 2010; 16: 2634-45. doi: 10.1158/1078-0432.CCR-09-2042.

190. Klijn JG, Berns PM, Schmitz PI, Foekens JA. The clinical significance of epidermal growth factor receptor (EGF-R) in human breast cancer: a review on 5232 patients. Endocr Rev. 1992; 13: 3-17. doi: 10.1210/edrv-13-1-3.

191. Di Fiore PP, Pierce JH, Fleming TP, Hazan R, Ullrich A, King CR, Schlessinger J, Aaronson SA. Overexpression of the human EGF receptor confers an EGF-dependent transformed phenotype to NIH 3 T3 cells. Cell. 1987; 51: 1063-70.

192. Fischer OM, Hart S, Gschwind A, Ullrich A. EGFR signal transactivation in cancer cells. Biochem Soc Trans. 2003; 31: 1203-8. doi: 10.1042/.
193. Yarden Y, Shilo BZ. SnapShot: EGFR signaling pathway. Cell. 2007; 131: 1018. doi: 10.1016/j.cell.2007.11.013.

194. Mendelsohn J, Baselga J. The EGF receptor family as targets for cancer therapy. Oncogene. 2000; 19: 6550-65. doi: 10.1038/sj.onc. 1204082 .

195. Carpenter G, King L, Jr., Cohen S. Epidermal growth factor stimulates phosphorylation in membrane preparations in vitro. Nature. 1978; 276: 409-10. doi:

196. Citri A, Yarden Y. EGF-ERBB signalling: towards the systems level. Nat Rev Mol Cell Biol. 2006; 7: 505-16. doi: 10.1038/nrm1962.

197. Yarden Y. The EGFR family and its ligands in human cancer. signalling mechanisms and therapeutic opportunities. Eur J Cancer. 2001; 37 Suppl 4: S3-8. doi:

198. Normanno N, De Luca A, Bianco C, Strizzi L, Mancino M, Maiello MR, Carotenuto A, De Feo G, Caponigro F, Salomon DS. Epidermal growth factor receptor (EGFR) signaling in cancer. Gene. 2006; 366: 2-16. doi: 10.1016/j. gene.2005.10.018.

199. Bogdan S, Klambt C. Epidermal growth factor receptor signaling. Curr Biol. 2001; 11: R292-5.

200. Lo HW, Ali-Seyed M, Wu Y, Bartholomeusz G, Hsu SC, Hung MC. Nuclear-cytoplasmic transport of EGFR involves receptor endocytosis, importin beta1 and CRM1. J Cell Biochem. 2006; 98: 1570-83. doi: 10.1002/jcb.20876.

201. Lo HW, Hsu SC, Hung MC. EGFR signaling pathway in breast cancers: from traditional signal transduction to direct nuclear translocalization. Breast Cancer Res Treat. 2006; 95: 211-8. doi: 10.1007/s 10549-005-9011-0.

202. Lo HW, Hung MC. Nuclear EGFR signalling network in cancers: linking EGFR pathway to cell cycle progression, nitric oxide pathway and patient survival. Br J Cancer. 2006; 94: 184-8. doi: 10.1038/sj.bjc.6602941.

203. Lin SY, Makino K, Xia W, Matin A, Wen Y, Kwong KY, Bourguignon L, Hung MC. Nuclear localization of EGF receptor and its potential new role as a transcription factor. Nat Cell Biol. 2001; 3: 802-8. doi: 10.1038/ncb0901-802.

204. Liao HJ, Carpenter G. Regulated intramembrane cleavage of the EGF receptor. Traffic. 2012; 13: 1106-12. doi: 10.1111/j.1600-0854.2012.01371.x.

205. Perez-Torres M, Valle BL, Maihle NJ, Negron-Vega L, Nieves-Alicea R, Cora EM. Shedding of epidermal growth factor receptor is a regulated process that occurs with overexpression in malignant cells. Exp Cell Res. 2008; 314 : 2907-18. doi: 10.1016/j.yexcr.2008.07.013.

206. Sanderson MP, Keller S, Alonso A, Riedle S, Dempsey PJ, Altevogt P. Generation of novel, secreted epidermal growth factor receptor (EGFR/ErbB1) isoforms via metalloprotease-dependent ectodomain shedding and exosome secretion. J Cell Biochem. 2008; 103: 1783-97. doi: $10.1002 /$ jcb.21569.

207. Gasch C, Bauernhofer T, Pichler M, Langer-Freitag S, Reeh M, Seifert AM, Mauermann O, Izbicki JR, Pantel K, Riethdorf S. Heterogeneity of epidermal growth 
factor receptor status and mutations of $\mathrm{KRAS} / \mathrm{PIK} 3 \mathrm{CA}$ in circulating tumor cells of patients with colorectal cancer. Clin Chem. 2013; 59: 252-60. doi: 10.1373/ clinchem.2012.188557.

208. Breitenbuecher F, Hoffarth S, Worm K, Cortes-Incio D, Gauler TC, Kohler J, Herold T, Schmid KW, Freitag L, Kasper S, Schuler M. Development of a highly sensitive and specific method for detection of circulating tumor cells harboring somatic mutations in non-small-cell lung cancer patients. PLoS One. 2014; 9: e85350. doi: 10.1371/journal. pone.0085350.

209. Kuboki Y, Matsusaka S, Minowa S, Shibata H, Suenaga M, Shinozaki E, Mizunuma N, Ueno M, Yamaguchi T, Hatake K. Circulating tumor cell (CTC) count and epithelial growth factor receptor expression on CTCs as biomarkers for cetuximab efficacy in advanced colorectal cancer. Anticancer Res. 2013; 33: 3905-10. doi:

210. Payne RE, Yague E, Slade MJ, Apostolopoulos C, Jiao LR, Ward B, Coombes RC, Stebbing J. Measurements of EGFR expression on circulating tumor cells are reproducible over time in metastatic breast cancer patients. Pharmacogenomics. 2009; 10: 51-7. doi: 10.2217/14622416.10.1.51.

211. Kalykaki A, Agelaki S, Kallergi G, Xyrafas A, Mavroudis D, Georgoulias V. Elimination of EGFR-expressing circulating tumor cells in patients with metastatic breast cancer treated with gefitinib. Cancer Chemother Pharmacol. 2014; 73: 685-93. doi: 10.1007/s00280-014-2387-y.

212. Serrano MJ, Ortega FG, Alvarez-Cubero MJ, Nadal R, Sanchez-Rovira P, Salido M, Rodriguez M, Garcia-Puche JL, Delgado-Rodriguez M, Sole F, Garcia MA, Peran M, Rosell R, et al. EMT and EGFR in CTCs cytokeratin negative non-metastatic breast cancer. Oncotarget. 2014; 5: 7486-97. doi: 10.18632/oncotarget.2217.

213. Yonesaka K, Zejnullahu K, Okamoto I, Satoh T, Cappuzzo F, Souglakos J, Ercan D, Rogers A, Roncalli M, Takeda M, Fujisaka Y, Philips J, Shimizu T, et al. Activation of ERBB2 signaling causes resistance to the EGFR-directed therapeutic antibody cetuximab. Sci Transl Med. 2011; 3: 99ra86. doi: 10.1126/scitranslmed.3002442.

214. Herrlich P, Zoller M, Pals ST, Ponta H. CD44 splice variants: metastases meet lymphocytes. Immunol Today. 1993; 14: 395-9. doi: 10.1016/0167-5699(93)90141-7.

215. Koopman G, Griffioen AW, Ponta H, Herrlich P, van den Berg F, Manten-Horst E, Pals ST. CD44 splice variants; expression on lymphocytes and in neoplasia. Res Immunol. 1993; 144: 750-4; discussion 4-62.

216. Pals ST, Koopman G, Heider KH, Griffioen A, Adolf GR, Van den Berg F, Ponta H, Herrlich P, Horst E. CD44 splice variants: expression during lymphocyte activation and tumor progression. Behring Inst Mitt. 1993: 273-7.

217. Ponta H, Sherman L, Herrlich PA. CD44: from adhesion molecules to signalling regulators. Nat Rev Mol Cell Biol. 2003; $4: 33-45$.
218. Underhill C. CD44: the hyaluronan receptor. J Cell Sci. 1992; 103 ( Pt 2): 293-8.

219. Aruffo A, Stamenkovic I, Melnick M, Underhill CB, Seed B. CD44 is the principal cell surface receptor for hyaluronate. Cell. 1990; 61: 1303-13.

220. Bourguignon LY, Spevak CC, Wong G, Xia W, Gilad E. Hyaluronan-CD44 interaction with protein kinase $\mathrm{C}$ (epsilon) promotes oncogenic signaling by the stem cell marker Nanog and the Production of microRNA-21, leading to down-regulation of the tumor suppressor protein PDCD4, anti-apoptosis, and chemotherapy resistance in breast tumor cells. J Biol Chem. 2009; 284: 26533-46. doi: M109.027466 [pii]10.1074/jbc.M109.027466.

221. Bourguignon LY, Wong G, Earle C, Krueger K, Spevak CC. Hyaluronan-CD44 Interaction Promotes c-Src-mediated Twist Signaling, MicroRNA-10b Expression, and RhoA/ RhoC Up-regulation, Leading to Rho-kinase-associated Cytoskeleton Activation and Breast Tumor Cell Invasion. J Biol Chem. 2010; 285: 36721-35. doi: M110.162305 [pii]10.1074/jbc.M110.162305.

222. Bourguignon LY, Xia W, Wong G. Hyaluronan-mediated CD44 interaction with $\mathrm{p} 300$ and SIRT1 regulates betacatenin signaling and NFkappaB-specific transcription activity leading to MDR1 and Bcl-xL gene expression and chemoresistance in breast tumor cells. J Biol Chem. 2009; 284: 2657-71. doi: M806708200 [pii]10.1074/jbc. M806708200.

223. Marhaba R, Bourouba M, Zoller M. CD44v6 promotes proliferation by persisting activation of MAP kinases. Cell Signal. 2005; 17: 961-73.

224. Gunthert U, Hofmann M, Rudy W, Reber S, Zoller M, Haussmann I, Matzku S, Wenzel A, Ponta H, Herrlich P. A new variant of glycoprotein CD44 confers metastatic potential to rat carcinoma cells. Cell. 1991; 65: 13-24. doi:

225. Okamoto I, Kawano Y, Tsuiki H, Sasaki J, Nakao M, Matsumoto M, Suga M, Ando M, Nakajima M, Saya H. CD44 cleavage induced by a membrane-associated metalloprotease plays a critical role in tumor cell migration. Oncogene. 1999; 18: 1435-46.

226. Dalerba P, Dylla SJ, Park IK, Liu R, Wang X, Cho RW, Hoey T, Gurney A, Huang EH, Simeone DM, Shelton AA, Parmiani G, Castelli C, et al. Phenotypic characterization of human colorectal cancer stem cells. Proc Natl Acad Sci U S A. 2007 ; 104: 10158-63.

227. Zhu Z, Hao X, Yan M, Yao M, Ge C, Gu J, Li J. Cancer stem/progenitor cells are highly enriched in CD133+CD44+ population in hepatocellular carcinoma. Int J Cancer. 2010; 126: 2067-78. doi: 10.1002/ijc.24868.

228. Prince ME, Sivanandan R, Kaczorowski A, Wolf GT, Kaplan MJ, Dalerba P, Weissman IL, Clarke MF, Ailles LE. Identification of a subpopulation of cells with cancer stem cell properties in head and neck squamous cell carcinoma. Proc Natl Acad Sci U S A. 2007; 104: 973-8.

229. Leung EL, Fiscus RR, Tung JW, Tin VP, Cheng LC, Sihoe 
AD, Fink LM, Ma Y, Wong MP. Non-small cell lung cancer cells expressing CD44 are enriched for stem celllike properties. PLoS One. 2010; 5: e14062. doi: 10.1371/ journal.pone.0014062.

230. Li C, Heidt DG, Dalerba P, Burant CF, Zhang L, Adsay V, Wicha M, Clarke MF, Simeone DM. Identification of pancreatic cancer stem cells. Cancer Res. 2007; 67: 1030-7.

231. Naor D, Wallach-Dayan SB, Zahalka MA, Sionov RV. Involvement of CD44, a molecule with a thousand faces, in cancer dissemination. Semin Cancer Biol. 2008; 18: 260-7.

232. Jin L, Hope KJ, Zhai Q, Smadja-Joffe F, Dick JE. Targeting of CD44 eradicates human acute myeloid leukemic stem cells. Nat Med. 2006; 12: 1167-74. doi: nm1483 [pii]10.1038/nm1483.

233. Jacobs PP, Sackstein R. CD44 and HCELL: preventing hematogenous metastasis at step 1. FEBS Lett. 2011; 585: 3148-58. doi: 10.1016/j.febslet.2011.07.039.

234. Burdick MM, Chu JT, Godar S, Sackstein R. HCELL is the major E- and L-selectin ligand expressed on LS174T colon carcinoma cells. J Biol Chem. 2006; 281: 13899-905. doi: 10.1074/jbc.M513617200.

235. Willingham SB, Volkmer JP, Gentles AJ, Sahoo D, Dalerba P, Mitra SS, Wang J, Contreras-Trujillo H, Martin R, Cohen JD, Lovelace P, Scheeren FA, Chao MP, et al. The CD47-signal regulatory protein alpha (SIRPa) interaction is a therapeutic target for human solid tumors. Proc Natl Acad Sci U S A. 2012; 109: 6662-7. doi: 10.1073/ pnas. 1121623109.

236. Baccelli I, Stenzinger A, Vogel V, Pfitzner BM, Klein C, Wallwiener M, Scharpff M, Saini M, Holland-Letz T, Sinn HP, Schneeweiss A, Denkert C, Weichert W, et al. Co-expression of MET and CD47 is a novel prognosticator for survival of luminal breast cancer patients. Oncotarget. 2014; 5: 8147-60. doi: 10.18632/oncotarget.2385.

237. Yap TA, Olmos D, Brunetto AT, Tunariu N, Barriuso J, Riisnaes R, Pope L, Clark J, Futreal A, Germuska M, Collins D, deSouza NM, Leach MO, et al. Phase I trial of a selective c-MET inhibitor ARQ 197 incorporating proof of mechanism pharmacodynamic studies. J Clin Oncol. 2011; 29: 1271-9. doi: 10.1200/JCO.2010.31.0367.

238. Yap TA, Sandhu SK, Alam SM, de Bono JS. HGF/c-MET targeted therapeutics: novel strategies for cancer medicine. Curr Drug Targets. 2011; 12: 2045-58.

239. Steinert G, Scholch S, Niemietz T, Iwata N, Garcia SA, Behrens B, Voigt A, Kloor M, Benner A, Bork U, Rahbari NN, Buchler MW, Stoecklein NH, et al. Immune escape and survival mechanisms in circulating tumor cells of colorectal cancer. Cancer Res. 2014; 74: 1694-704. doi: 10.1158/0008-5472.CAN-13-1885.

240. van Noort V, Scholch S, Iskar M, Zeller G, Ostertag K, Schweitzer C, Werner K, Weitz J, Koch M, Bork P. Novel drug candidates for the treatment of metastatic colorectal cancer through global inverse gene-expression profiling. Cancer Res. 2014; 74: 5690-9. doi: 10.1158/0008-5472.
CAN-13-3540.

241. Chen L, Han X. Anti-PD-1/PD-L1 therapy of human cancer: past, present, and future. J Clin Invest. 2015; 125: 3384-91. doi: 10.1172/JCI80011.

242. Sheppard KA, Fitz LJ, Lee JM, Benander C, George JA, Wooters J, Qiu Y, Jussif JM, Carter LL, Wood CR, Chaudhary D. PD-1 inhibits T-cell receptor induced phosphorylation of the ZAP70/CD3zeta signalosome and downstream signaling to PKCtheta. FEBS Lett. 2004; 574: 37-41. doi: 10.1016/j.febslet.2004.07.083.

243. Freeman GJ, Long AJ, Iwai Y, Bourque K, Chernova T, Nishimura H, Fitz LJ, Malenkovich N, Okazaki T, Byrne MC, Horton HF, Fouser L, Carter L, et al. Engagement of the PD-1 immunoinhibitory receptor by a novel B7 family member leads to negative regulation of lymphocyte activation. J Exp Med. 2000; 192: 1027-34.

244. Iwai Y, Ishida M, Tanaka Y, Okazaki T, Honjo T, Minato $\mathrm{N}$. Involvement of PD-L1 on tumor cells in the escape from host immune system and tumor immunotherapy by PD-L1 blockade. Proc Natl Acad Sci U S A. 2002; 99: 12293-7. doi: 10.1073/pnas.192461099.

245. Dong H, Strome SE, Salomao DR, Tamura H, Hirano F, Flies DB, Roche PC, Lu J, Zhu G, Tamada K, Lennon VA, Celis E, Chen L. Tumor-associated B7-H1 promotes T-cell apoptosis: a potential mechanism of immune evasion. Nat Med. 2002; 8: 793-800. doi: 10.1038/nm730.

246. Marincola FM, Jaffee EM, Hicklin DJ, Ferrone S. Escape of human solid tumors from T-cell recognition: molecular mechanisms and functional significance. Adv Immunol. 2000; 74: 181-273. doi:

247. Hamanishi J, Mandai M, Iwasaki M, Okazaki T, Tanaka Y, Yamaguchi K, Higuchi T, Yagi H, Takakura K, Minato N, Honjo T, Fujii S. Programmed cell death 1 ligand 1 and tumor-infiltrating CD8+ $\mathrm{T}$ lymphocytes are prognostic factors of human ovarian cancer. Proc Natl Acad Sci U S A. 2007; 104: 3360-5. doi: 10.1073/pnas.0611533104.

248. Hirano F, Kaneko K, Tamura H, Dong H, Wang S, Ichikawa M, Rietz C, Flies DB, Lau JS, Zhu G, Tamada K, Chen L. Blockade of B7-H1 and PD-1 by monoclonal antibodies potentiates cancer therapeutic immunity. Cancer Res. 2005; 65: 1089-96. doi:

249. Wu P, Wu D, Li L, Chai Y, Huang J. PD-L1 and Survival in Solid Tumors: A Meta-Analysis. PLoS One. 2015; 10: e0131403. doi: 10.1371/journal.pone.0131403.

250. Hamanishi J, Mandai M, Matsumura N, Abiko K, Baba T, Konishi I. PD-1/PD-L1 blockade in cancer treatment: perspectives and issues. Int J Clin Oncol. 2016; 21: 462-73. doi: 10.1007/s10147-016-0959-z.

251. Mandai M, Hamanishi J, Abiko K, Matsumura N, Baba T, Konishi I. Anti-PD-L1/PD-1 immune therapies in ovarian cancer: basic mechanism and future clinical application. Int J Clin Oncol. 2016; 21: 456-61. doi: 10.1007/s10147-0160968-y.

252. Swaika A, Hammond WA, Joseph RW. Current 
state of anti-PD-L1 and anti-PD-1 agents in cancer therapy. Mol Immunol. 2015; 67: 4-17. doi: 10.1016/j. molimm.2015.02.009.

253. Mazel M, Jacot W, Pantel K, Bartkowiak K, Topart D, Cayrefourcq L, Rossille D, Maudelonde T, Fest T, AlixPanabieres C. Frequent expression of PD-L1 on circulating breast cancer cells. Mol Oncol. 2015; 9: 1773-82. doi: 10.1016/j.molonc.2015.05.009.

254. David R. PD-L1 expression by circulating breast cancer cells. Lancet Oncol. 2015; 16: e321. doi: 10.1016/S14702045(15)00074-1.

255. Oliveira-Costa JP, de Carvalho AF, da Silveira da GG, Amaya P, Wu Y, Park KJ, Gigliola MP, Lustberg M, Buim ME, Ferreira EN, Kowalski LP, Chalmers JJ, Soares FA, et al. Gene expression patterns through oral squamous cell carcinoma development: PD-L1 expression in primary tumor and circulating tumor cells. Oncotarget. 2015; 6: 20902-20. doi: 10.18632/oncotarget.3939.

256. Satelli A, Batth IS, Brownlee Z, Rojas C, Meng QH, Kopetz S, Li S. Potential role of nuclear PD-L1 expression in cell-surface vimentin positive circulating tumor cells as a prognostic marker in cancer patients. Sci Rep. 2016; 6: 28910. doi: 10.1038/srep28910.

257. Abiko K, Mandai M, Hamanishi J, Yoshioka Y, Matsumura N, Baba T, Yamaguchi K, Murakami R, Yamamoto A, Kharma B, Kosaka K, Konishi I. PD-L1 on tumor cells is induced in ascites and promotes peritoneal dissemination of ovarian cancer through CTL dysfunction. Clin Cancer Res. 2013; 19: 1363-74. doi: 10.1158/1078-0432.CCR-12-2199.

258. Mocellin S, Hoon D, Ambrosi A, Nitti D, Rossi CR. The prognostic value of circulating tumor cells in patients with melanoma: a systematic review and meta-analysis. Clin Cancer Res. 2006; 12: 4605-13. doi: 10.1158/1078-0432. CCR-06-0823.

259. Khan MS, Kirkwood A, Tsigani T, Garcia-Hernandez J, Hartley JA, Caplin ME, Meyer T. Circulating tumor cells as prognostic markers in neuroendocrine tumors. J Clin Oncol. 2013; 31: 365-72. doi: 10.1200/JCO.2012.44.2905.

260. Krebs MG, Sloane R, Priest L, Lancashire L, Hou JM, Greystoke A, Ward TH, Ferraldeschi R, Hughes A, Clack G, Ranson M, Dive C, Blackhall FH. Evaluation and prognostic significance of circulating tumor cells in patients with non-small-cell lung cancer. J Clin Oncol. 2011; 29: 1556-63. doi: 10.1200/JCO.2010.28.7045.

261. Han L, Chen W, Zhao Q. Prognostic value of circulating tumor cells in patients with pancreatic cancer: a metaanalysis. Tumour Biol. 2014; 35: 2473-80. doi: 10.1007/ s13277-013-1327-5.

262. Wu XL, Tu Q, Faure G, Gallet P, Kohler C, Bittencourt Mde C. Diagnostic and Prognostic Value of Circulating Tumor Cells in Head and Neck Squamous Cell Carcinoma: a systematic review and meta-analysis. Sci Rep. 2016; 6: 20210. doi: 10.1038/srep20210.

263. Hyun KA, Goo KB, Han H, Sohn J, Choi W, Kim SI,
Jung HI, Kim YS. Epithelial-to-mesenchymal transition leads to loss of EpCAM and different physical properties in circulating tumor cells from metastatic breast cancer. Oncotarget. 2016; 7:24677-8. doi: 10.18632/ oncotarget. 8250 .

264. Theodoropoulos PA, Polioudaki H, Agelaki S, Kallergi G, Saridaki Z, Mavroudis D, Georgoulias V. Circulating tumor cells with a putative stem cell phenotype in peripheral blood of patients with breast cancer. Cancer Lett. 2010; 288: 99106. doi: 10.1016/j.canlet.2009.06.027.

265. Balasubramanian P, Lang JC, Jatana KR, Miller B, Ozer E, Old M, Schuller DE, Agrawal A, Teknos TN, Summers TA, Jr., Lustberg MB, Zborowski M, Chalmers JJ. Multiparameter analysis, including EMT markers, on negatively enriched blood samples from patients with squamous cell carcinoma of the head and neck. PLoS One. 2012; 7: e42048. doi: 10.1371/journal.pone.0042048.

266. Giordano A, Gao H, Anfossi S, Cohen E, Mego M, Lee BN, Tin S, De Laurentiis M, Parker CA, Alvarez RH, Valero V, Ueno NT, De Placido S, et al. Epithelial-mesenchymal transition and stem cell markers in patients with HER2positive metastatic breast cancer. Mol Cancer Ther. 2012; 11: 2526-34. doi: 10.1158/1535-7163.MCT-12-0460.

267. Alonso-Alconada L, Muinelo-Romay L, Madissoo K, DiazLopez A, Krakstad C, Trovik J, Wik E, Hapangama D, Coenegrachts L, Cano A, Gil-Moreno A, Chiva L, Cueva $\mathrm{J}$, et al. Molecular profiling of circulating tumor cells links plasticity to the metastatic process in endometrial cancer. Mol Cancer. 2014; 13: 223. doi: 10.1186/1476-4598-13223.

268. Toyoshima K, Hayashi A, Kashiwagi M, Hayashi N, Iwatsuki M, Ishimoto T, Baba Y, Baba H, Ohta Y. Analysis of circulating tumor cells derived from advanced gastric cancer. Int J Cancer. 2015; 137: 991-8. doi: 10.1002/ ijc. 29455 .

269. Aktas B, Tewes M, Fehm T, Hauch S, Kimmig R, KasimirBauer S. Stem cell and epithelial-mesenchymal transition markers are frequently overexpressed in circulating tumor cells of metastatic breast cancer patients. Breast Cancer Res. 2009; 11: R46. doi: 10.1186/bcr2333.

270. Malara N, Trunzo V, Foresta U, Amodio N, De Vitis S, Roveda L, Fava M, Coluccio M, Macri R, Di Vito A, Costa N, Mignogna C, Britti D, et al. Ex-vivo characterization of circulating colon cancer cells distinguished in stem and differentiated subset provides useful biomarker for personalized metastatic risk assessment. J Transl Med. 2016; 14: 133. doi: 10.1186/s12967-016-0876-y.

271. Nel I, Gauler TC, Bublitz K, Lazaridis L, Goergens A, Giebel B, Schuler M, Hoffmann AC. Circulating Tumor Cell Composition in Renal Cell Carcinoma. PLoS One. 2016; 11: e0153018. doi: 10.1371/journal.pone.0153018.

272. Shimada R, Iinuma H, Akahane T, Horiuchi A, Watanabe T. Prognostic significance of CTCs and CSCs of tumor drainage vein blood in Dukes' stage B and C colorectal cancer patients. Oncol Rep. 2012; 27: 947-53. doi: 10.3892/ 
or.2012.1649.

273. Nel I, Jehn U, Gauler T, Hoffmann AC. Individual profiling of circulating tumor cell composition in patients with nonsmall cell lung cancer receiving platinum based treatment. Transl Lung Cancer Res. 2014; 3: 100-6. doi: 10.3978/j. issn.2218-6751.2014.03.05.

274. Sun YF, Xu Y, Yang XR, Guo W, Zhang X, Qiu SJ, Shi RY, Hu B, Zhou J, Fan J. Circulating stem cell-like epithelial cell adhesion molecule-positive tumor cells indicate poor prognosis of hepatocellular carcinoma after curative resection. Hepatology. 2013; 57: 1458-68. doi: 10.1002/hep.26151.

275. Nadal R, Ortega FG, Salido M, Lorente JA, RodriguezRivera M, Delgado-Rodriguez M, Macia M, Fernandez A, Corominas JM, Garcia-Puche JL, Sanchez-Rovira P, Sole F, Serrano MJ. CD133 expression in circulating tumor cells from breast cancer patients: potential role in resistance to chemotherapy. Int J Cancer. 2013; 133: 2398-407. doi: 10.1002/ijc.28263.

276. Alix-Panabieres C. EPISPOT assay: detection of viable DTCs/CTCs in solid tumor patients. Recent Results Cancer Res. 2012; 195: 69-76. doi: 10.1007/978-3-642-28160-0_6.

277. Kolostova K, Pinkas M, Jakabova A, Pospisilova E, Svobodova P, Spicka J, Cegan M, Matkowski R, Bobek $\mathrm{V}$. Molecular characterization of circulating tumor cells in ovarian cancer. Am J Cancer Res. 2016; 6: 973-80. doi:

278. Kubisch I, de Albuquerque A, Schuppan D, Kaul S, Schaich M, Stolzel U. Prognostic Role of a Multimarker Analysis of Circulating Tumor Cells in Advanced Gastric and Gastroesophageal Adenocarcinomas. Oncology. 2015; 89: 294-303. doi: 10.1159/000437373.

279. de Albuquerque A, Kaul S, Breier G, Krabisch P, Fersis N. Multimarker Analysis of Circulating Tumor Cells in Peripheral Blood of Metastatic Breast Cancer Patients: A Step Forward in Personalized Medicine. Breast Care (Basel). 2012; 7: 7-12. doi: 10.1159/000336548.

280. Zhang T, Boominathan R, Foulk B, Rao C, Kemeny G, Strickler JH, Abbruzzese JL, Harrison MR, Hsu DS, Healy P, Li J, Pi C, Prendergast KM, et al. Development of a novel c-MET based CTC detection platform. Mol Cancer Res. 2016. doi: 10.1158/1541-7786.MCR-16-0011.

281. Lu Y, Liang H, Yu T, Xie J, Chen S, Dong H, Sinko PJ, Lian S, Xu J, Wang J, Yu S, Shao J, Yuan B, et al. Isolation and characterization of living circulating tumor cells in patients by immunomagnetic negative enrichment coupled with flow cytometry. Cancer. 2015; 121: 3036-45. doi: 10.1002/cncr.29444.

282. Aktas B, Kasimir-Bauer S, Heubner M, Kimmig R, Wimberger P. Molecular profiling and prognostic relevance of circulating tumor cells in the blood of ovarian cancer patients at primary diagnosis and after platinum-based chemotherapy. Int J Gynecol Cancer. 2011; 21: 822-30. doi: 10.1097/IGC.0b013e318216cb91.

283. Pestrin M, Bessi S, Puglisi F, Minisini AM, Masci G,
Battelli N, Ravaioli A, Gianni L, Di Marsico R, Tondini C, Gori S, Coombes CR, Stebbing J, et al. Final results of a multicenter phase II clinical trial evaluating the activity of single-agent lapatinib in patients with HER2-negative metastatic breast cancer and HER2-positive circulating tumor cells. A proof-of-concept study. Breast Cancer Res Treat. 2012; 134: 283-9. doi: 10.1007/s10549-012-2045-1.

284. Zhang L, Ridgway LD, Wetzel MD, Ngo J, Yin W, Kumar D, Goodman JC, Groves MD, Marchetti D. The identification and characterization of breast cancer CTCs competent for brain metastasis. Sci Transl Med. 2013; 5: 180ra48. doi: 10.1126/scitranslmed.3005109.

285. Lankiewicz S, Rother E, Zimmermann S, Hollmann C, Korangy F, Greten TF. Tumour-associated transcripts and EGFR deletion variants in colorectal cancer in primary tumour, metastases and circulating tumour cells. Cell Oncol. 2008; 30: 463-71.

286. Kolostova K, Matkowski R, Gurlich R, Grabowski K, Soter K, Lischke R, Schutzner J, Bobek V. Detection and cultivation of circulating tumor cells in gastric cancer. Cytotechnology. 2015. doi: 10.1007/s10616-015-9866-9.

287. Grisanti S, Almici C, Consoli F, Buglione M, Verardi R, Bolzoni-Villaret A, Bianchetti A, Ciccarese C, Mangoni M, Ferrari L, Biti G, Marini M, Ferrari VD, et al. Circulating tumor cells in patients with recurrent or metastatic head and neck carcinoma: prognostic and predictive significance. PLoS One. 2014; 9: e103918. doi: 10.1371/journal. pone. 0103918 .

288. Shaffer DR, Leversha MA, Danila DC, Lin O, GonzalezEspinoza R, Gu B, Anand A, Smith K, Maslak P, Doyle GV, Terstappen LW, Lilja H, Heller G, et al. Circulating tumor cell analysis in patients with progressive castrationresistant prostate cancer. Clin Cancer Res. 2007; 13: 2023 9. doi: 10.1158/1078-0432.CCR-06-2701.

289. Sundaresan TK, Sequist LV, Heymach JV, Riely GJ, Janne PA, Koch WH, Sullivan JP, Fox DB, Maher R, Muzikansky A, Webb A, Tran HT, Giri U, et al. Detection of T790M, the Acquired Resistance EGFR Mutation, by Tumor Biopsy versus Noninvasive Blood-Based Analyses. Clin Cancer Res. 2016; 22: 1103-10. doi: 10.1158/1078-0432.CCR-151031.

290. Stebbing J, Payne R, Reise J, Frampton AE, Avery M, Woodley L, Di Leo A, Pestrin M, Krell J, Coombes RC. The efficacy of lapatinib in metastatic breast cancer with HER2 non-amplified primary tumors and EGFR positive circulating tumor cells: a proof-of-concept study. PLoS One. 2013; 8: e62543. doi: 10.1371/journal.pone.0062543.

291. Theodoro TR, de Matos LL, Sant Anna AV, Fonseca FL, Semedo P, Martins LC, Nader HB, Del Giglio A, da Silva Pinhal MA. Heparanase expression in circulating lymphocytes of breast cancer patients depends on the presence of the primary tumor and/or systemic metastasis. Neoplasia. 2007; 9: 504-10.

292. Scher HI, Lu D, Schreiber NA, Louw J, Graf RP, Vargas HA, Johnson A, Jendrisak A, Bambury R, Danila D, 
McLaughlin B, Wahl J, Greene SB, et al. Association of AR-V7 on Circulating Tumor Cells as a Treatment-Specific Biomarker With Outcomes and Survival in CastrationResistant Prostate Cancer. JAMA Oncol. 2016. doi: 10.1001/jamaoncol.2016.1828.

293. Goldkorn A, Ely B, Tangen CM, Tai YC, Xu T, Li H, Twardowski P, Veldhuizen PJ, Agarwal N, Carducci MA, Monk JP, 3rd, Garzotto M, Mack PC, et al. Circulating tumor cell telomerase activity as a prognostic marker for overall survival in SWOG 0421: a phase III metastatic castration resistant prostate cancer trial. Int J Cancer. 2015; 136: 1856-62. doi: 10.1002/ijc.29212.

294. Ma Y, Hao S, Wang S, Zhao Y, Lim B, Lei M, Spector DJ, El-Deiry WS, Zheng SY, Zhu J. A Combinatory Strategy for Detection of Live CTCs Using Microfiltration and a New Telomerase-Selective Adenovirus. Mol Cancer Ther. 2015; 14: 835-43. doi: 10.1158/1535-7163.MCT-14-0693.

295. Yabusaki M, Sato J, Kohyama A, Kojima T, Nobuoka D, Yoshikawa T, Sawada Y, Murakami K, Gohda K, Okegawa T, Nakamura M, Takamatsu K, Ito M, et al. Detection and preliminary evaluation of circulating tumor cells in the peripheral blood of patients with eight types of cancer using a telomerase-specific adenovirus. Oncol Rep. 2014; 32: 1772-8. doi: 10.3892/or.2014.3436.

296. Lindsay CR, Le Moulec S, Billiot F, Loriot Y, Ngo-Camus M, Vielh P, Fizazi K, Massard C, Farace F. Vimentin and Ki67 expression in circulating tumour cells derived from castrate-resistant prostate cancer. BMC Cancer. 2016; 16: 168. doi: 10.1186/s12885-016-2192-6.

297. Wang HY, Ahn S, Kim S, Park S, Jung D, Park S, Han H, Sohn J, Kim S, Lee H. Detection of circulating tumor cell-specific markers in breast cancer patients using the quantitative RT-PCR assay. Int J Clin Oncol. 2015; 20: 87890. doi: 10.1007/s10147-015-0798-3.

298. Paoletti C, Muniz MC, Thomas DG, Griffith KA, Kidwell KM, Tokudome N, Brown ME, Aung K, Miller MC, Blossom DL, Schott AF, Henry NL, Rae JM, et al. Development of circulating tumor cell-endocrine therapy index in patients with hormone receptor-positive breast cancer. Clin Cancer Res. 2015; 21: 2487-98. doi: 10.1158/1078-0432.CCR-14-1913.

299. Kallergi G, Konstantinidis G, Markomanolaki H, Papadaki MA, Mavroudis D, Stournaras C, Georgoulias V, Agelaki $\mathrm{S}$. Apoptotic circulating tumor cells in early and metastatic breast cancer patients. Mol Cancer Ther. 2013; 12: 1886-95. doi: 10.1158/1535-7163.MCT-12-1167.

300. Vishnoi M, Peddibhotla S, Yin W, A TS, George GC, Hong DS, Marchetti D. The isolation and characterization of CTC subsets related to breast cancer dormancy. Sci Rep. 2015; 5: 17533. doi: 10.1038/srep17533.

301. Meng S, Tripathy D, Shete S, Ashfaq R, Saboorian H, Haley B, Frenkel E, Euhus D, Leitch M, Osborne C, Clifford E, Perkins S, Beitsch P, et al. uPAR and HER-2 gene status in individual breast cancer cells from blood and tissues. Proc Natl Acad Sci U S A. 2006; 103: 17361-5. doi: 10.1073/ pnas.0608113103.

302. Balic M, Lin H, Young L, Hawes D, Giuliano A, McNamara G, Datar RH, Cote RJ. Most early disseminated cancer cells detected in bone marrow of breast cancer patients have a putative breast cancer stem cell phenotype. Clin Cancer Res. 2006; 12: 5615-21. doi: 10.1158/1078-0432.CCR-060169 .

303. Wu P, Tang RN, Zou JH, Wang FC. The prognostic role of disseminated tumor cells detected in peripheral blood and bone marrow of colorectal cancer. Hepatogastroenterology. 2012; 59: 2164-7. doi: 10.5754/hge12539.

304. Tjensvoll K, Oltedal S, Heikkila R, Kvaloy JT, Gilje B, Reuben JM, Smaaland R, Nordgard O. Persistent tumor cells in bone marrow of non-metastatic breast cancer patients after primary surgery are associated with inferior outcome. BMC Cancer. 2012; 12: 190. doi: 10.1186/14712407-12-190.

305. Gilje B, Nordgard O, Tjensvoll K, Borgen E, Synnestvedt M, Smaaland R, Naume B. Comparison of molecular and immunocytochemical methods for detection of disseminated tumor cells in bone marrow from early breast cancer patients. BMC Cancer. 2014; 14: 514. doi: 10.1186/14712407-14-514.

306. Thomas C, Wiesner C, Melchior SW, Schmidt F, Gillitzer R, Thuroff JW, Pfitzenmaier J. Urokinase-plasminogenactivator receptor expression in disseminated tumour cells in the bone marrow and peripheral blood of patients with clinically localized prostate cancer. BJU Int. 2009; 104: 2934. doi: 10.1111/j.1464-410X.2008.08298.x.

307. Schindlbeck C, Jeschke U, Schulze S, Karsten U, Janni W, Rack B, Sommer H, Friese K. Characterisation of disseminated tumor cells in the bone marrow of breast cancer patients by the Thomsen-Friedenreich tumor antigen. Histochem Cell Biol. 2005; 123: 631-7. doi: 10.1007/ s00418-005-0781-6.

308. Schindlbeck C, Hantschmann P, Zerzer M, Jahns B, Rjosk D, Janni W, Rack B, Sommer H, Friese K. Prognostic impact of KI67, p53, human epithelial growth factor receptor 2, topoisomerase IIalpha, epidermal growth factor receptor, and nm23 expression of ovarian carcinomas and disseminated tumor cells in the bone marrow. Int $\mathrm{J}$ Gynecol Cancer. 2007; 17: 1047-55. doi: 10.1111/j.15251438.2007.00920.x.

309. Schindlbeck C, Kampik T, Janni W, Rack B, Jeschke U, Krajewski S, Sommer H, Friese K. Prognostic relevance of disseminated tumor cells in the bone marrow and biological factors of 265 primary breast carcinomas. Breast Cancer Res. 2005; 7: R1174-85. doi: 10.1186/bcr1360.

310. Hartkopf AD, Banys M, Meier-Stiegen F, Hahn M, Rohm C, Hoffmann J, Helms G, Taran FA, Wallwiener M, Walter C, Neubauer H, Wallwiener D, Fehm T. The HER2 status of disseminated tumor cells in the bone marrow of early breast cancer patients is independent from primary tumor and predicts higher risk of relapse. Breast Cancer Res Treat. 2013; 138: 509-17. doi: 10.1007/s10549-013-2470-9. 
311. Braun S, Schlimok G, Heumos I, Schaller G, Riethdorf L, Riethmuller G, Pantel K. ErbB2 overexpression on occult metastatic cells in bone marrow predicts poor clinical outcome of stage I-III breast cancer patients. Cancer Res. 2001; 61: 1890-5.

312. Jager BA, Finkenzeller C, Bock C, Majunke L, Jueckstock JK, Andergassen U, Neugebauer JK, Pestka A, Friedl TW, Jeschke U, Janni W, Doisneau-Sixou SF, Rack BK. Estrogen Receptor and HER2 Status on Disseminated Tumor Cells and Primary Tumor in Patients with Early Breast Cancer. Transl Oncol. 2015; 8: 509-16. doi: 10.1016/j.tranon.2015.11.009.

313. Zhang J, Shen KW, Liu G, Zhou J, Shen Q, Shen ZZ, Shao ZM. Antigenic profiles of disseminated breast tumour cells and microenvironment in bone marrow. Eur J Surg Oncol. 2003; 29: 121-6.

314. Pantel K, Schlimok G, Braun S, Kutter D, Lindemann F, Schaller G, Funke I, Izbicki JR, Riethmuller G. Differential expression of proliferation-associated molecules in individual micrometastatic carcinoma cells. J Natl Cancer Inst. 1993; 85: 1419-24.

315. Zieglschmid V, Hollmann C, Mannel J, Albert W, Jaeschke-Melli S, Eckstein B, Hillemann T, Greten TF, Gross E, Bocher O. Tumor-associated gene expression in disseminated tumor cells correlates with disease progression and tumor stage in colorectal cancer. Anticancer Res. 2007; 27: 1823-32.

316. Silva HA, Abraul E, Raimundo D, Dias MF, Marques C, Guerra C, de Oliveira CF, Regateiro FJ. Molecular detection of EGFRvIII-positive cells in the peripheral blood of breast cancer patients. Eur J Cancer. 2006; 42: 2617-22. doi: 10.1016/j.ejca.2006.03.033.

317. Chery L, Lam HM, Coleman I, Lakely B, Coleman R, Larson S, Aguirre-Ghiso JA, Xia J, Gulati R, Nelson PS, Montgomery B, Lange P, Snyder LA, et al. Characterization of single disseminated prostate cancer cells reveals tumor cell heterogeneity and identifies dormancy associated pathways. Oncotarget. 2014; 5: 9939-51. doi: 10.18632/ oncotarget. 2480 .

318. Dardaei L, Shahsavani R, Ghavamzadeh A, Behmanesh
M, Aslankoohi E, Alimoghaddam K, Ghaffari SH. The detection of disseminated tumor cells in bone marrow and peripheral blood of gastric cancer patients by multimarker (CEA, CK20, TFF1 and MUC2) quantitative real-time PCR. Clin Biochem. 2011; 44: 325-30. doi: 10.1016/j. clinbiochem.2010.11.005.

319. Berois N, Varangot M, Aizen B, Estrugo R, Zarantonelli L, Fernandez P, Krygier G, Simonet F, Barrios E, Muse I, Osinaga E. Molecular detection of cancer cells in bone marrow and peripheral blood of patients with operable breast cancer. Comparison of CK19, MUC1 and CEA using RT-PCR. Eur J Cancer. 2000; 36: 717-23.

320. Rud AK, Boye K, Fodstad O, Juell S, Jorgensen LH, Solberg S, Helland A, Brustugun OT, Maelandsmo GM. Detection of disseminated tumor cells in lymph nodes from patients with early stage non-small cell lung cancer. Diagn Pathol. 2016; 11: 50. doi: 10.1186/s13000-016-0504-4.

321. Dhayat S, Sorescu S, Vallbohmer D, Kraus S, Baldus SE, Rehders A, Kropil F, Krieg A, Knoefel WT, Stoecklein NH. Prognostic Significance of EpCAM-Positive Disseminated Tumor Cells in Rectal Cancer Patients With Stage I Disease. Am J Surg Pathol. 2012; 36: 1809-16. doi: 10.1097/PAS.0b013e318265288c.

322. Wimberger P, Heubner M, Otterbach F, Fehm T, Kimmig $\mathrm{R}$, Kasimir-Bauer S. Influence of platinum-based chemotherapy on disseminated tumor cells in blood and bone marrow of patients with ovarian cancer. Gynecol Oncol. 2007; 107: 331-8. doi: 10.1016/j.ygyno.2007.07.073.

323. Braun S, Hepp F, Kentenich CR, Janni W, Pantel K, Riethmuller G, Willgeroth F, Sommer HL. Monoclonal antibody therapy with edrecolomab in breast cancer patients: monitoring of elimination of disseminated cytokeratin-positive tumor cells in bone marrow. Clin Cancer Res. 1999; 5: 3999-4004.

324. Braun S, Vogl FD, Naume B, Janni W, Osborne MP, Coombes RC, Schlimok G, Diel IJ, Gerber B, Gebauer G, Pierga JY, Marth C, Oruzio D, et al. A pooled analysis of bone marrow micrometastasis in breast cancer. $\mathrm{N}$ Engl $\mathrm{J}$ Med. 2005; 353: 793-802. 